\title{
LEVEL II SCOUR ANALYSIS FOR BRIDGE 2 (STAMVT01000002) on STATE ROUTE 100, crossing ROARING BROOK, STAMFORD, VERMONT
}

U.S. Geological Survey Open-File Report 97-211

Prepared in cooperation with

VERMONT AGENCY OF TRANSPORTATION and

FEDERAL HIGHWAY ADMINISTRATION 


\section{LEVEL II SCOUR ANALYSIS FOR BRIDGE 2 (STAMVT01000002) on STATE ROUTE 100, crossing ROARING BROOK, STAMFORD, VERMONT}

By ERICK M. BOEHMLER and ROBERT E. HAMMOND

U.S. Geological Survey Open-File Report 97-211

Prepared in cooperation with

VERMONT AGENCY OF TRANSPORTATION

and

FEDERAL HIGHWAY ADMINISTRATION 


\title{
U.S. DEPARTMENT OF THE INTERIOR BRUCE BABBITT, Secretary
}

\author{
U.S. GEOLOGICAL SURVEY \\ Gordon P. Eaton, Director
}

For additional information write to:

District Chief

U.S. Geological Survey 361 Commerce Way

Pembroke, NH 03275-3718
Copies of this report may be purchased from:

U.S. Geological Survey

Branch of Information Services

Open-File Reports Unit

Box 25286

Denver, CO 80225-0286 


\section{CONTENTS}

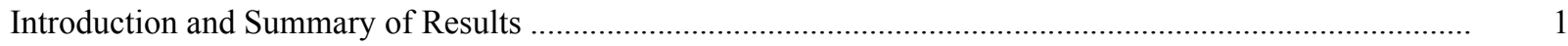

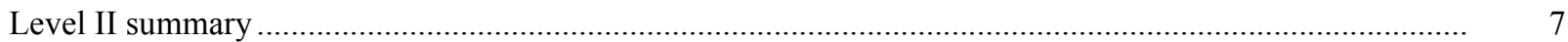

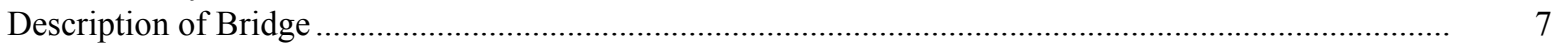

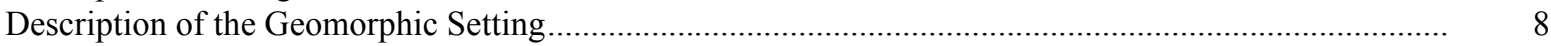

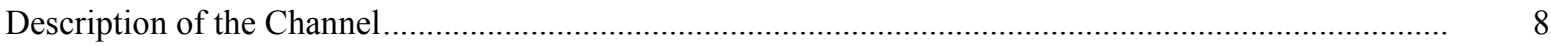

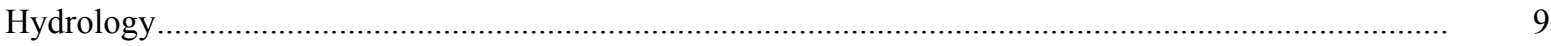

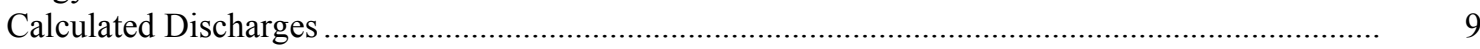

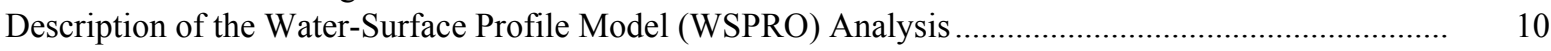

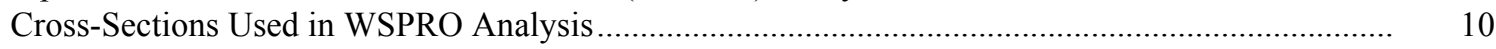

Data and Assumptions Used in WSPRO Model ...................................................................... 11

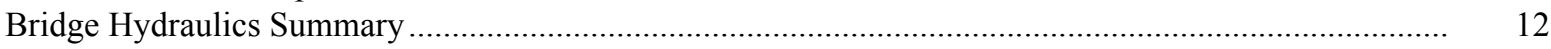

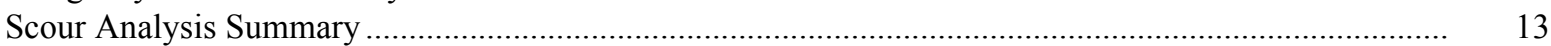

Special Conditions or Assumptions Made in Scour Analysis ...................................................... 13

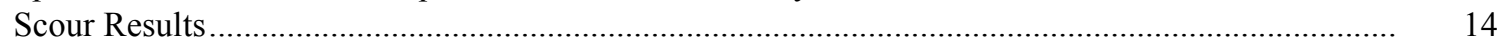

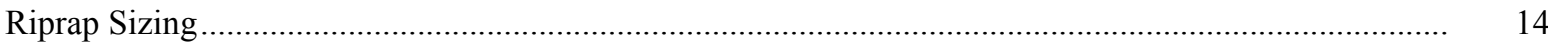

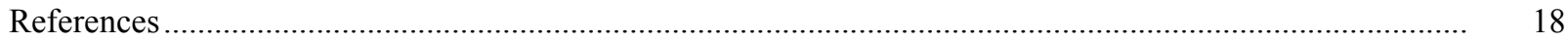

Appendixes:

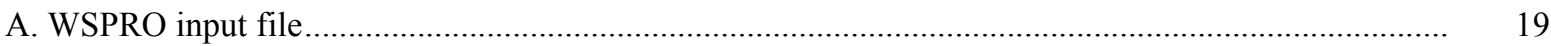

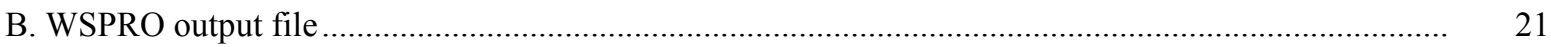

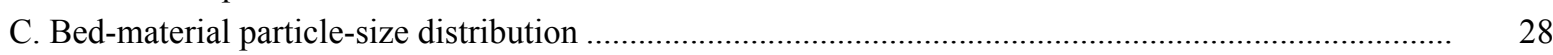

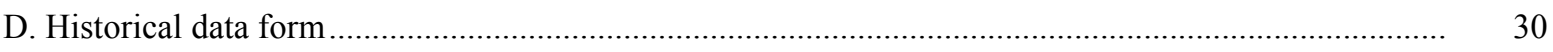

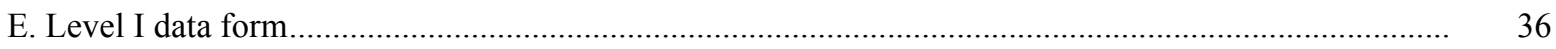

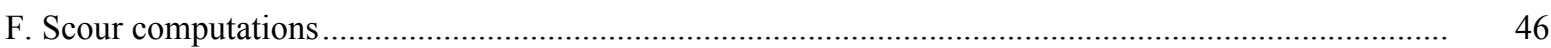

\section{FIGURES}

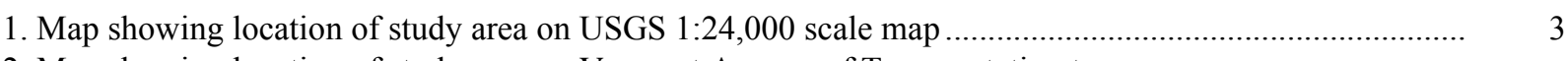

2. Map showing location of study area on Vermont Agency of Transportation town
highway map

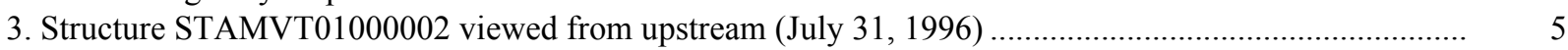

4. Downstream channel viewed from structure STAMVT01000002 (July 31, 1996)............................... 5

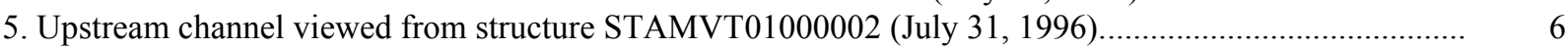

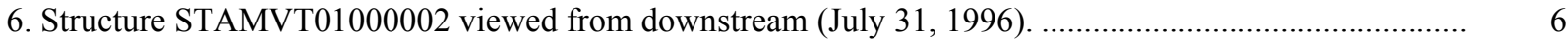

7. Water-surface profiles for the 100- and 500-year discharges at structure

STAMVT01000002 on State Route 100, crossing Roaring Brook,

Stamford, Vermont.

8. Scour elevations for the 100- and 500-year discharges at structure

STAMVT01000002 on State Route 100, crossing Roaring Brook,

Stamford, Vermont.

\section{TABLES}

1. Remaining footing/pile depth at abutments for the 100-year discharge at structure

STAMVT01000002 on State Route 100, crossing Roaring Brook,

Stamford, Vermont.

2. Remaining footing/pile depth at abutments for the 500-year discharge at structure

STAMVT01000002 on State Route 100, crossing Roaring Brook,

Stamford, Vermont. 


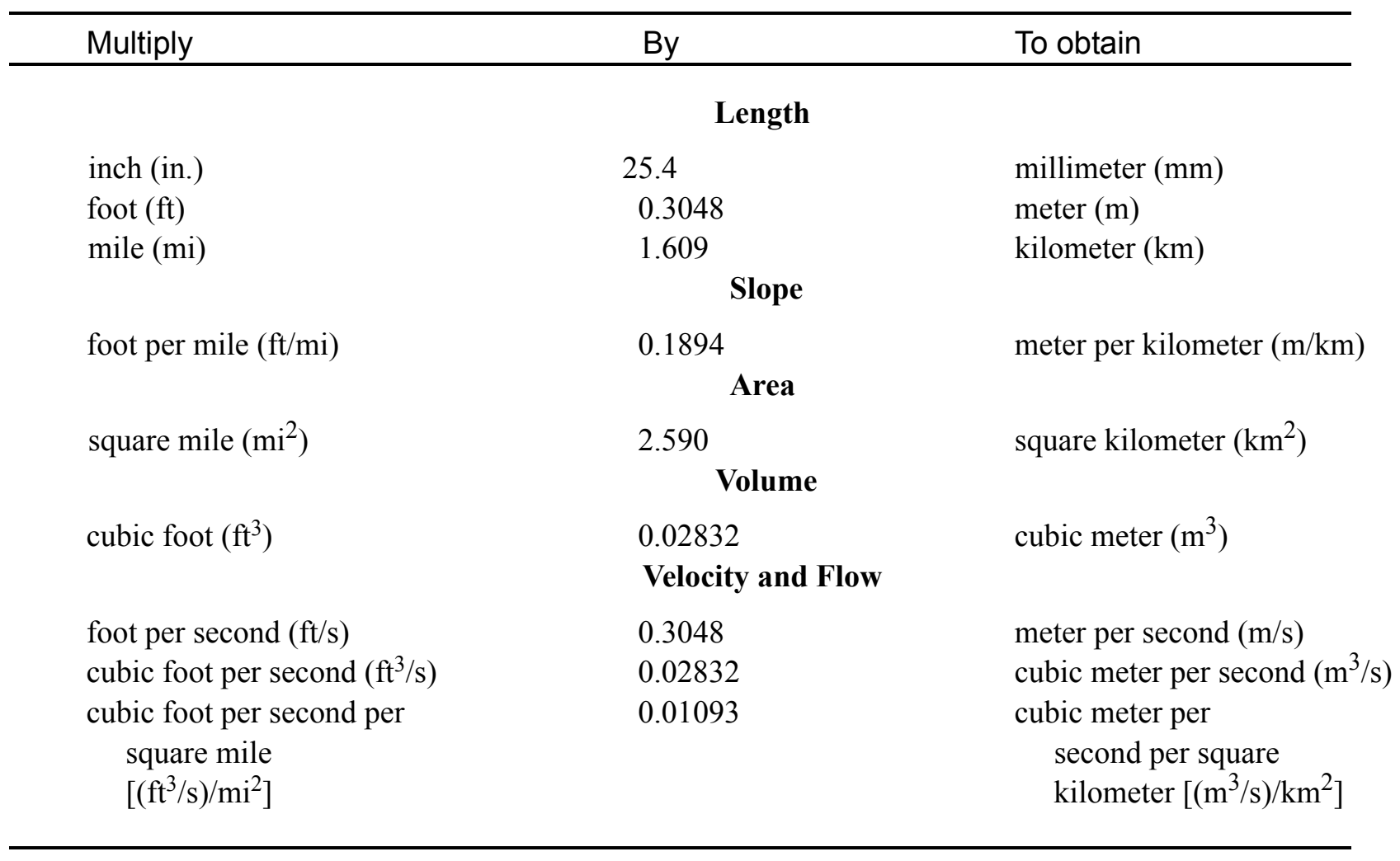

\section{OTHER ABBREVIATIONS}

$\begin{array}{lrlr}\mathrm{BF} & \text { bank full } & \text { LWW } & \text { left wingwall } \\ \mathrm{cfs} & \text { cubic feet per second } & \text { MC } & \text { main channel } \\ \mathrm{D}_{50} & \text { median diameter of bed material } & \text { RAB } & \text { right abutment } \\ \mathrm{DS} & \text { downstream } & \text { RABUT } & \text { face of right abutment } \\ \mathrm{elev} & \text { elevation } & \text { RB } & \text { right bank } \\ \mathrm{f} / \mathrm{p} & \text { flood plain } & \text { ROB } & \text { right overbank } \\ \mathrm{ft}^{2} & \text { square feet } & \text { RWW } & \text { right wingwall } \\ \mathrm{ft} / \mathrm{ft} & \text { feet per foot } & \text { TH } & \text { town highway } \\ \mathrm{JCT} & \text { junction } & \text { UB } & \text { under bridge } \\ \mathrm{LAB} & \text { left abutment } & \text { US } & \text { upstream } \\ \mathrm{LABUT} & \text { face of left abutment } & \text { USGS } & \text { United States Geological Survey } \\ \mathrm{LB} & \text { left bank } & \text { VTAOT Vermont Agency of Transportation } \\ \mathrm{LOB} & \text { left overbank } & \text { WSPRO } & \text { water-surface profile model }\end{array}$

In this report, the words "right" and "left" refer to directions that would be reported by an observer facing downstream. Sea level: In this report, "sea level" refers to the National Geodetic Vertical Datum of 1929-- a geodetic datum derived from a general adjustment of the first-order level nets of the United States and Canada, formerly called Sea Level Datum of 1929.

In the appendices, the above abbreviations may be combined. For example, USLB would represent upstream left bank. 


\title{
LEVEL II SCOUR ANALYSIS FOR BRIDGE 2 (STAMVT01000002) ON STATE ROUTE 100, CROSSING ROARING BROOK, STAMFORD, VERMONT
}

\author{
By Erick M. Boehmler and Robert E. Hammond
}

\section{INTRODUCTION AND SUMMARY OF RESULTS}

This report provides the results of a detailed Level II analysis of scour potential at structure STAMVT01000002 on State Route 100 crossing Roaring Brook, Stamford, Vermont (figures 1-8). A Level II study is a basic engineering analysis of the site, including a quantitative analysis of stream stability and scour (U.S. Department of Transportation, 1993). Results of a Level I scour investigation also are included in Appendix E of this report. A Level I investigation provides a qualitative geomorphic characterization of the study site. Information on the bridge, gleaned from Vermont Agency of Transportation (VTAOT) files, was compiled prior to conducting Level I and Level II analyses and is found in Appendix D.

The site is in the Green Mountain section of the New England physiographic province in Southwestern Vermont. The $8.26-\mathrm{mi}^{2}$ drainage area is in a predominantly rural and forested basin. In the vicinity of the study site, the surface cover consists of houses with grass lawns, and trees on the right overbank areas upstream and downstream of the bridge. The left overbank areas upstream and downstream of the bridge are covered with trees and brush.

In the study area, Roaring Brook has a straight channel with a slope of approximately 0.02 $\mathrm{ft} / \mathrm{ft}$, an average channel top width of $56 \mathrm{ft}$ and an average bank height of $5 \mathrm{ft}$. The channel bed materials range from gravel to boulders with a median grain size $\left(\mathrm{D}_{50}\right)$ of $53.7 \mathrm{~mm}$ $(0.176 \mathrm{ft})$. The geomorphic assessment at the time of the Level I and Level II site visit on July 31,1996 , indicated that the reach was aggraded.

The State Route 100 crossing of Roaring Brook is a 44-ft-long, two-lane bridge consisting of one 42-foot steel-beam span (Vermont Agency of Transportation, written communication, September 28, 1995). The bridge is supported by vertical, concrete abutments with wingwalls. The channel is skewed approximately 5 degrees to the opening and the opening-skew-to-roadway is 5 degrees.

Scour protection measures at the site were type- 2 stone fill (less than 36 inches diameter) on the upstream banks and wingwalls, type-3 (less than 48 inches diameter) on the downstream wingwalls, and artificial levees made from a variety of materials on the downstream banks. Additional details describing conditions at the site are included in the Level II Summary and Appendices D and E. 
Scour depths and rock rip-rap sizes were computed using the general guidelines described in Hydraulic Engineering Circular 18 (Richardson and others, 1995). Total scour at a highway crossing is comprised of three components: 1) long-term streambed degradation; 2) contraction scour (due to accelerated flow caused by a reduction in flow area at a bridge) and; 3) local scour (caused by accelerated flow around piers and abutments). Total scour is the sum of the three components. Equations are available to compute depths for contraction and local scour and a summary of the results of these computations follows.

Contraction scour for all modelled flows ranged from 0.0 to 0.8 feet. The worst-case contraction scour occurred at the 100-year discharge. Abutment scour ranged from 4.2 to 9.3 feet. The worst-case abutment scour occurred at the 500-year discharge at the left abutment. Additional information on scour depths and depths to armoring are included in the section titled "Scour Results". Scoured-streambed elevations, based on the calculated scour depths, are presented in tables 1 and 2. A cross-section of the scour computed at the bridge is presented in figure 8 . Scour depths were calculated assuming an infinite depth of erosive material and a homogeneous particle-size distribution.

It is generally accepted that the Froehlich equation (abutment scour) gives "excessively conservative estimates of scour depths" (Richardson and others, 1995, p. 47). Usually, computed scour depths are evaluated in combination with other information including (but not limited to) historical performance during flood events, the geomorphic stability assessment, existing scour protection measures, and the results of the hydraulic analyses. Therefore, scour depths adopted by VTAOT may differ from the computed values documented herein. 


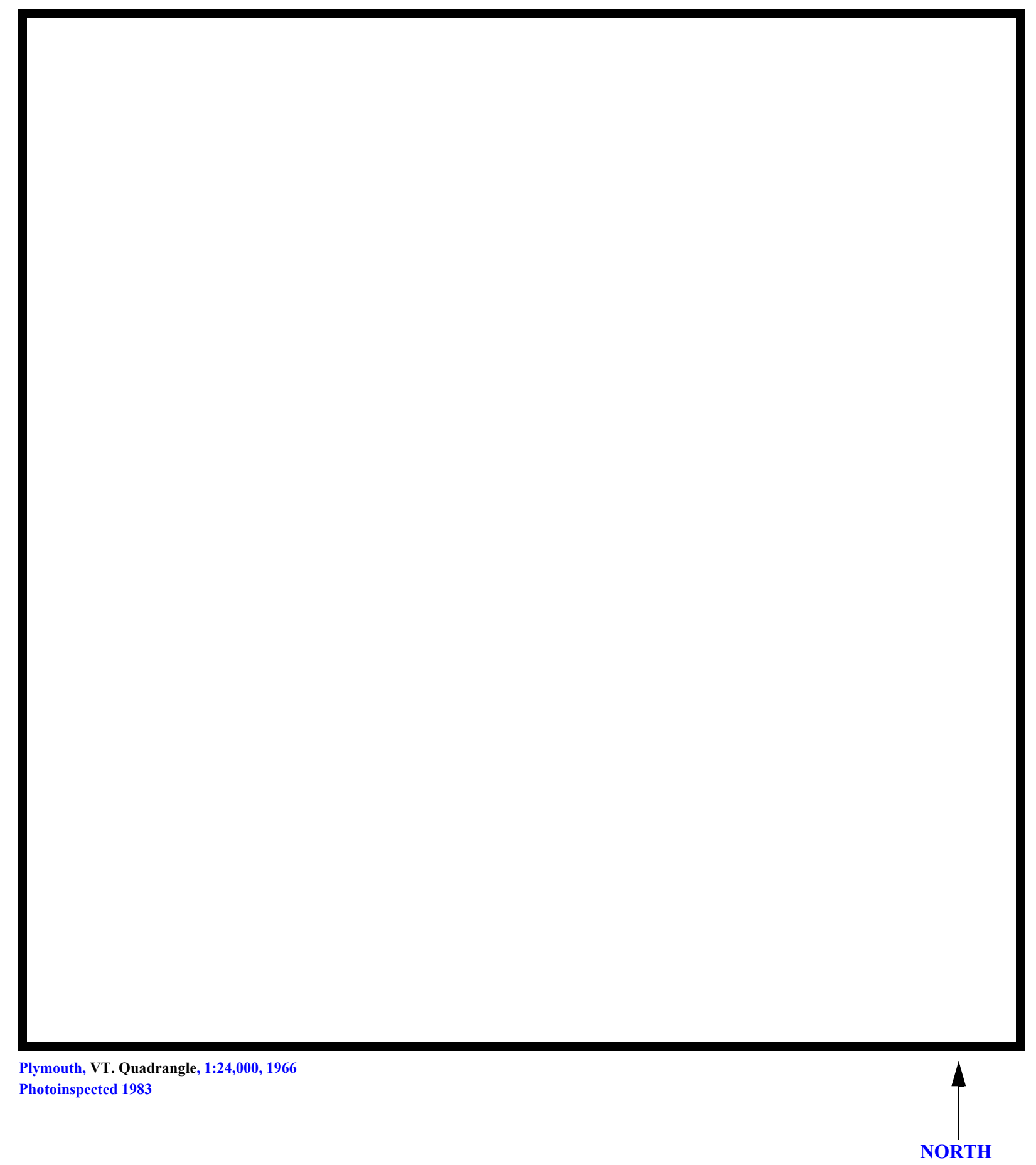

Figure 1. Location of study area on USGS 1:24,000 scale map. 
Figure 2. Location of study area on Vermont Agency of Transportation town highway map. 

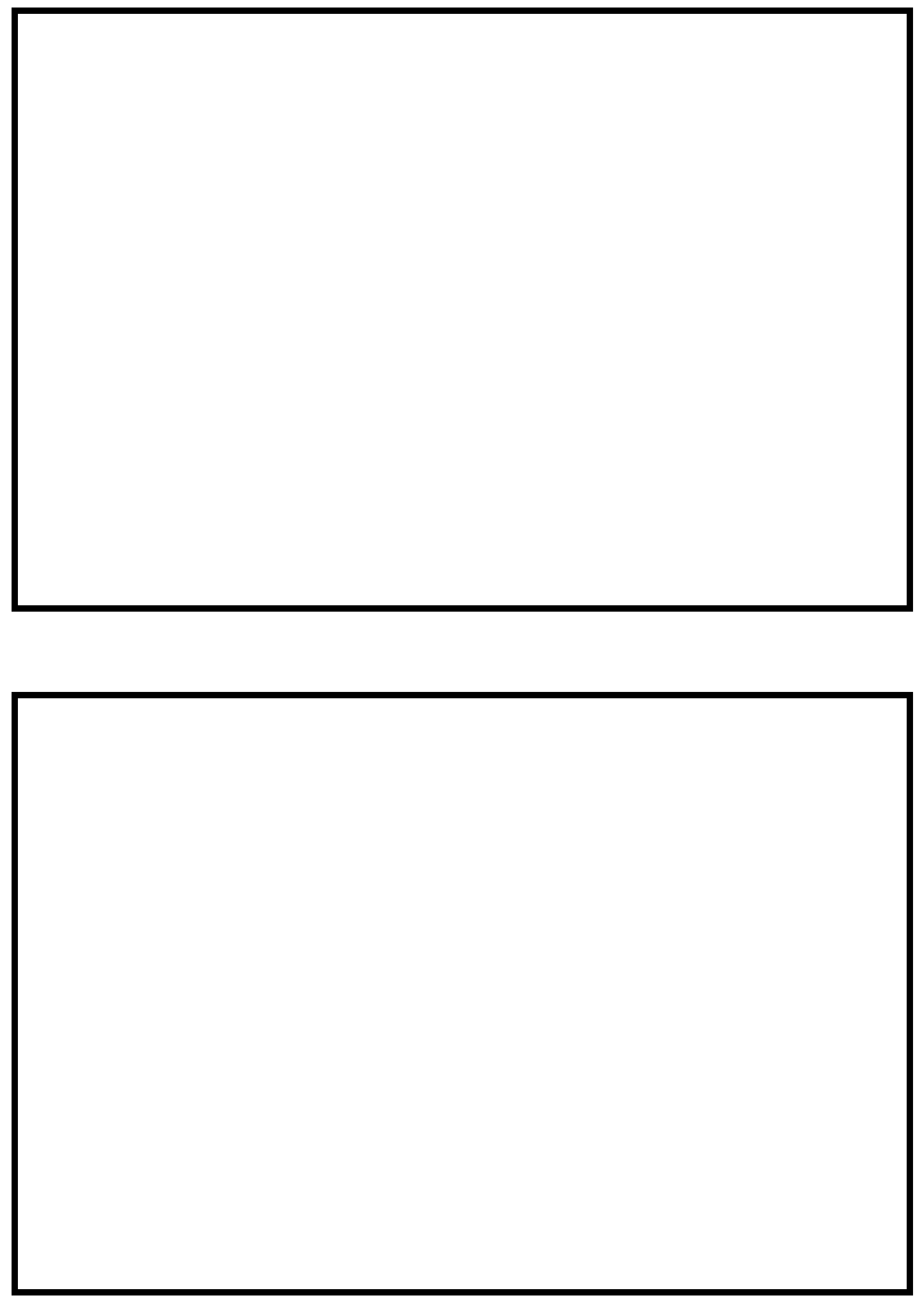

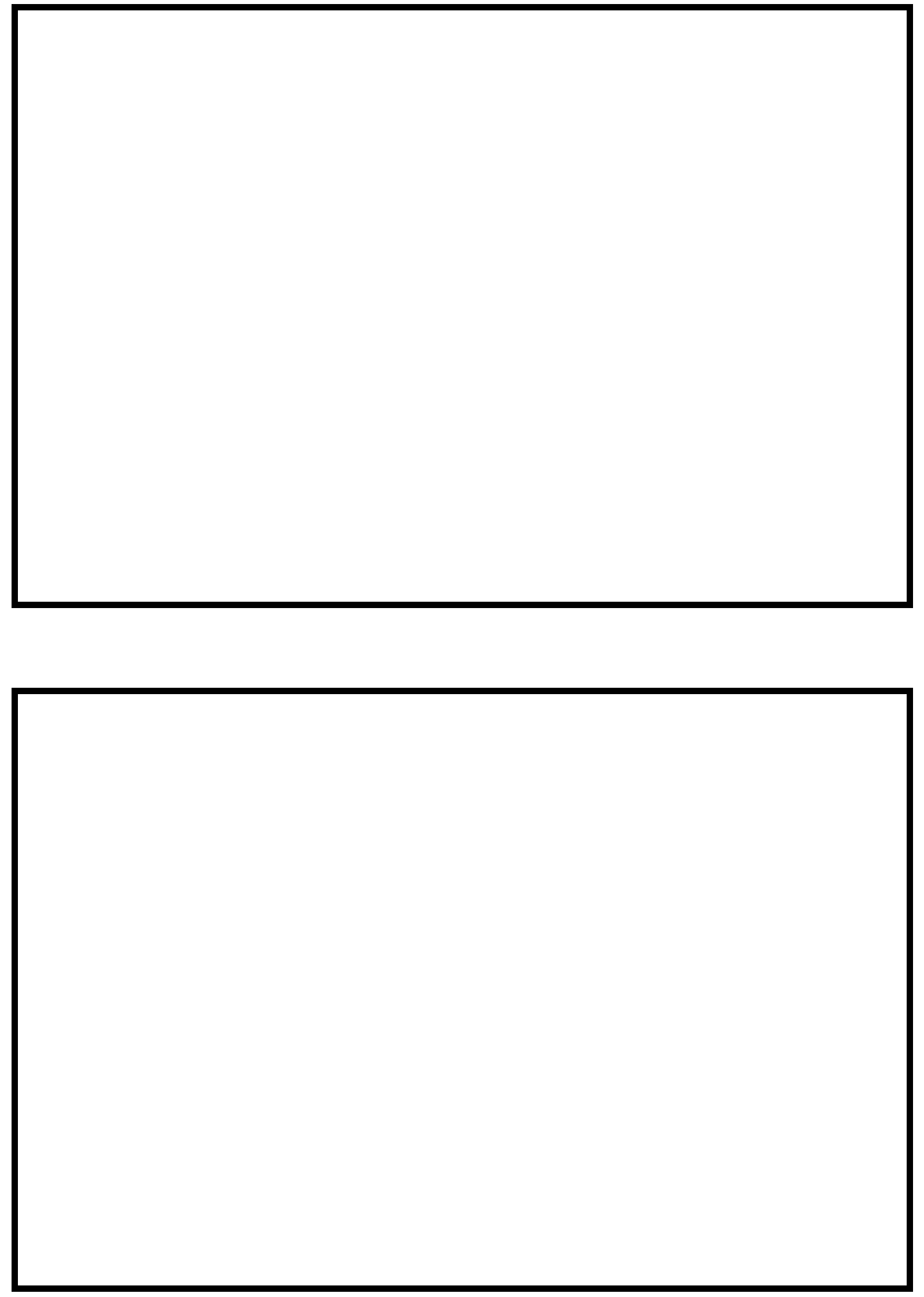


\section{LEVEL II SUMMARY}

\begin{tabular}{llllll} 
Structure Number & \multicolumn{2}{c}{ STAMVT01000002 } & Stream & \multicolumn{2}{c}{ Roaring Brook } \\
& & & & \\
County & Boad & VT 100 & District & 1
\end{tabular}

\section{Description of Bridge}

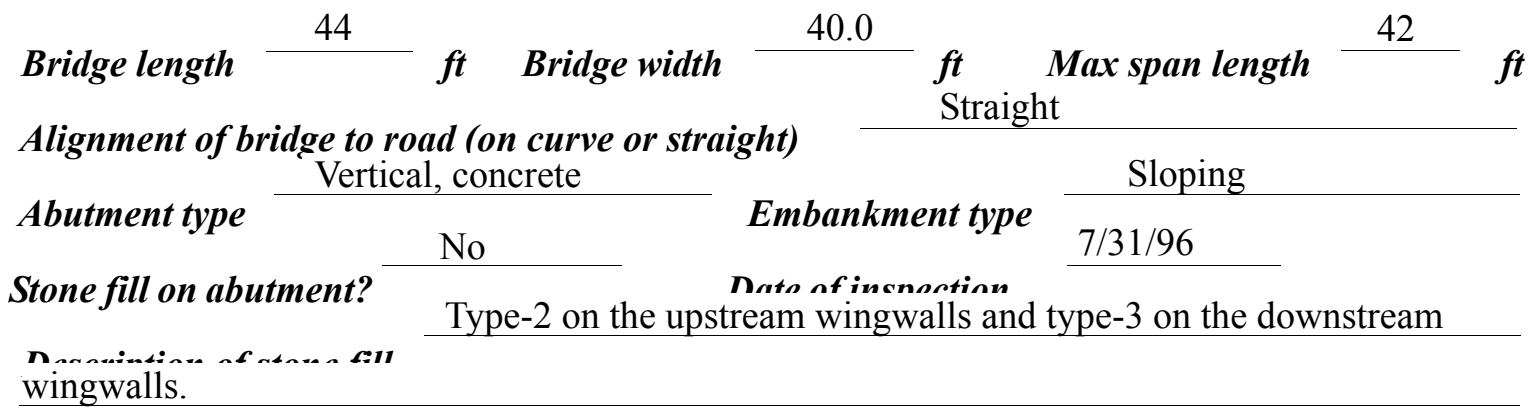

$\ldots \ldots . . . . .$.

Abutments and wingwalls are concrete.

Yes

Is bridge skewed to flood flow according to No ' survey? Angle

Debris accumulation on bridge at time of Level I or Level II site visit:

\begin{tabular}{|c|c|c|c|}
\hline & $\begin{array}{c}\text { Date of insnortion } \\
7 / 31 / 96 \\
\end{array}$ & $\begin{array}{l}\text { Percent of rhannol } \\
\text { blocked inortzontatly }\end{array}$ & $\begin{array}{l}\text { Percent of a } 0 \\
\text { blocked verticatty }\end{array}$ \\
\hline Level I & $7 / 31 / 96$ & 0 & 0 \\
\hline $\begin{array}{l}\text { Level II } \\
\text { at this site. }\end{array}$ & Moderate. & e are trees on the imme & inks, which are stable \\
\hline
\end{tabular}

Artificial levees were present on 7/31/96 on the banks through the reach to retain flow in the Doscriho anv foaturos noar ar at tho hridos that mov, affort flow, (includo ahsorvation dato) channel up to a foot and a half above the native bank level. 


\section{Description of the Geomorphic Setting}

General topography The channel has narrow, flat to slightly irregular flood plains with no distinctive valley.

Geomorphic conditions at bridge site: downstream (DS), upstream (US)

Date of inspection $\quad 7 / 31 / 96$

DS left: $\quad$ Moderately sloping channel bank to a narrow, irregular flood plain.

DS right: Steep channel bank to a wide flood plain.

US left: $\quad$ Moderately sloping channel bank to a narrow overbank.

US right: $\quad$ Moderately sloping channel bank to a narrow, irregular flood plain.

\section{Description of the Channel}

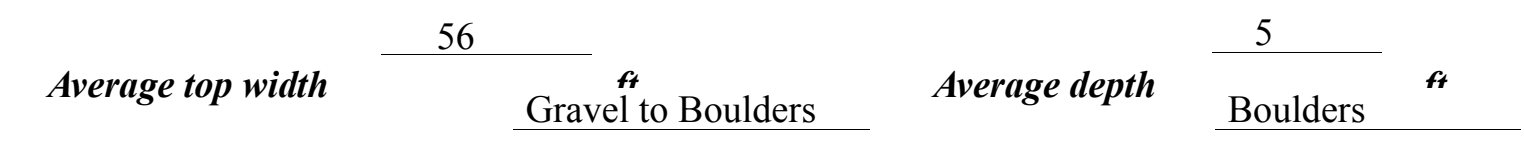

Predominant bed material

Bank material Channelized and

straight with semi-alluvial channel boundäries.

$7 / 31 / 96$

Vegetative co 1 Trees and brush

DS left: $\quad$ Trees and brush

DS right: $\quad$ Trees and brush

US left: $\quad$ Trees and brush.

US right: $\quad$ Yes

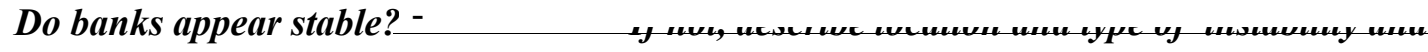

date of observation.

The assessment of

$7 / 31 / 96$ noted artificial levees on the banks through the reach, which prevent flow from spilling Describe any obstructions in channel and date of observation.

out on the flood plain for up to 1.5 feet higher than the native bank level. 


\section{Hydrology}

Drainage area $\stackrel{8.26}{\boldsymbol{m i}^{2}}$

Percentage of drainage area in physiographic provinces: (approximate)

Physiographic province/section

New England / Green Mountain
Percent of drainage area 100

Is drainage area considered rural or urban? Rural Describe any significant urbanization:

There are a couple houses on the right overbank areas upstream and downstream of the site.

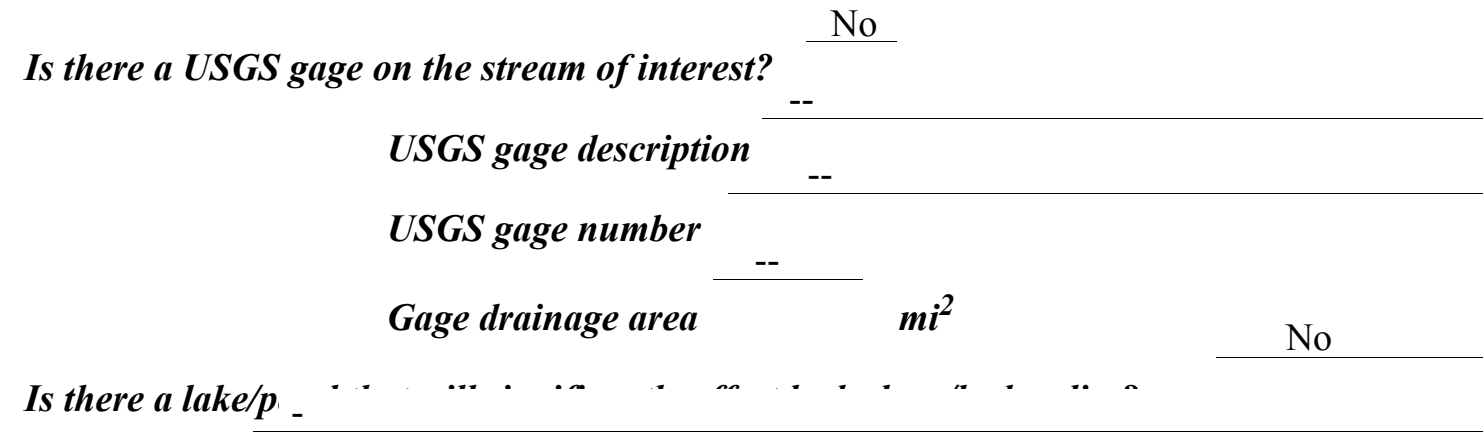

\section{Calculated Discharges $\quad 3,400$}

$0100 \quad 0500 \quad f t^{3} / s$

The 100- and 500-year discharges are based on

discharge frequency curves obtained from the VTAOT database and computed by use of several empirical equations (Benson, 1962; FHWA, 1983; Johnson and Laraway, unpublished draft, 1972; Johnson and Tasker, 1974; Potter, 1957a\&b; Talbot, 1887). Each curve was extrapolated to the 500-year event. Since the VTAOT database curve was central to the others, the curve was selected for the hydraulic analyses at this site. 


\section{Description of the Water-Surface Profile Model (WSPRO) Analysis}

Datum for WSPRO analysis (USGS survey, sea level, VTAOT plans)

USGS survey

Datum tie between USGS survey and VTAOT plans

Add 634.9 feet to the USGS

arbitrary survey datum to obtain the VTAOT plans' datum.

Description of reference marks used to determine USGS datum. $\quad$ RM1 is a metal VTAOT

survey marker disk set in the top of the downstream end of the right abutment (elev. $500.26 \mathrm{ft}$,

arbitrary survey datum). RM3 is a chiseled "V" in the top of the upstream end of the right

abutment (elev. $500.31 \mathrm{ft}$, arbitrary survey datum).

\section{Cross-Sections Used in WSPRO Analysis}

\begin{tabular}{cccl}
\hline${ }^{1}$ Cross-section & $\begin{array}{c}\text { Section } \\
\text { Reference } \\
\text { Distance } \\
\text { (SRD) in feet }\end{array}$ & $\begin{array}{c}{ }^{2} \text { Cross-section } \\
\text { development }\end{array}$ & \multicolumn{1}{c}{ Comments } \\
\hline EXITX & -43 & 1 & $\begin{array}{l}\text { Exit section } \\
\text { Downstream Full-valley } \\
\text { section (Templated from } \\
\text { FULLV }\end{array}$ EXITX) $^{\text {Bridge section }}$ \\
BRIDG & 0 & 2 & Road Grade section \\
RDWAY & 22 & 1 & Approach section \\
APPRO & 83 & 1 & \\
\hline
\end{tabular}

${ }^{1}$ For location of cross-sections see plan-view sketch included with Level I field form, Appendix E. For more detail on how cross-sections were developed see WSPRO input file. 


\section{Data and Assumptions Used in WSPRO Model}

Hydraulic analyses of the reach were done by use of the Federal Highway Administration's WSPRO step-backwater computer program (Shearman and others, 1986, and Shearman, 1990). The analyses reported herein reflect conditions existing at the site at the time of the study. Furthermore, in the development of the model it was necessary to assume no accumulation of debris or ice at the site. Results of the hydraulic model are presented in the Bridge Hydraulic Summary, Appendix B, and figure 7.

Channel roughness factors (Manning's " $n$ ") used in the hydraulic model were estimated using field inspections at each cross section following the general guidelines described by Arcement and Schneider (1989). Final adjustments to the values were made during the modelling of the reach. Channel " $n$ " values for the reach ranged from 0.045 to 0.065 , and overbank "n" values ranged from 0.055 to 0.075 .

For the 100- and 500-year events, WSPRO assumes critical depth as the starting water surface. Normal depth at the exit section was computed by use of the slope-conveyance method outlined in the user's manual for WSPRO (Shearman, 1990). For the 100- and 500-year events, normal depth was determined to be supercritical but within 0.4 feet of critical depth. Normal depth at the exit section was assumed as the starting water surface for the incipient overtopping discharge model. This depth also was computed by use of the slope-conveyance method and the same slope as used for the 100- and 500-year discharges.

The approach section (APPRO) was surveyed at one bridge length upstream of the upstream face as recommended by Shearman and others (1986). This location also provides a consistent method for determining scour variables. 


\section{Bridge Hydraulics Summary}

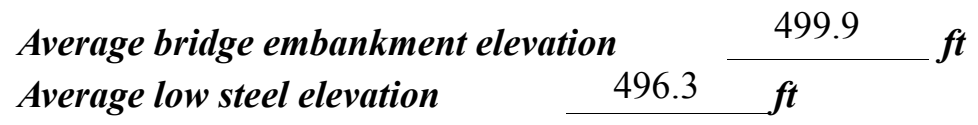

100-year discharge $\quad 2,450 \quad \mathrm{ft}^{3} / \mathrm{s}$

Water-surface elevation in bridge opening $\quad 496.3$ ft

Road overtopping? ___ Yes Discharge over road __ $778 \quad \mathrm{ft}^{3} / \mathrm{s}$

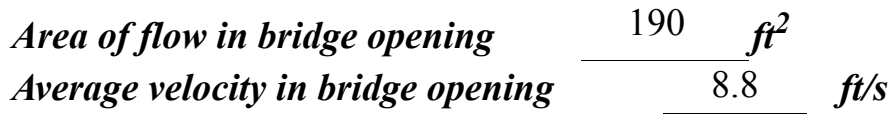

$\begin{array}{llll}\text { Maximum WSPRO tube velocity at bridge } & 12.1 \mathrm{ft} / \mathrm{s}\end{array}$

Water-surface elevation at Approach section with bridge $\quad 498.4$

Water-surface elevation at Approach section without bridge $\quad \overline{498.1}$

Amount of backwater caused by bridge $\quad 0.3 \quad$ it

500-year discharge $\quad 3,400 \quad \mathrm{ft}^{3} / \mathrm{s}$

Water-surface elevation in bridge opening $\quad 496.5 \mathrm{ft}$

Road overtopping? ___ Yes Discharge over road _ $1770 \mathrm{ft}^{3} / \mathrm{s}$

Area of flow in bridge opening $191 \quad \mathrm{ft}^{2}$

Average velocity in bridge opening $8.5 \mathrm{ft} / \mathrm{s}$

Maximum WSPRO tube velocity at bridge $\quad 9.9$ 's

Water-surface elevation at Approach section with bridge 498.9

Water-surface elevation at Approach section without bridge $\quad 498.4$

Amount of backwater caused by bridge 0.5 .

Incipient overtopping discharge $\quad 1,300 \mathrm{ft}^{3} / \mathrm{s}$

Water-surface elevation in bridge opening $496.5 \quad t$

Area of flow in bridge opening

$191 \quad \mathrm{ft}^{2}$

$\begin{array}{lll}\text { Average velocity in bridge opening } & 6.8 \mathrm{ft} / \mathrm{s}\end{array}$

Maximum WSPRO tube velocity at bridge $\quad 7.9 \mathrm{ft} / \mathrm{s}$

Water-surface elevation at Approach section with bridge

Water-surface elevation at Approach section without bridge

497.5

Amount of backwater caused by bridge $\quad 1.1$ it 


\section{Scour Analysis Summary}

\section{Special Conditions or Assumptions Made in Scour Analysis}

Scour depths were computed using the general guidelines described in Hydraulic Engineering Circular 18 (Richardson and others, 1995). Scour depths were calculated assuming an infinite depth of erosive material and a homogeneous particle-size distribution. The results of the scour analysis are presented in tables 1 and 2 and a graph of the scour depths is presented in figure 8.

All of the discharges modeled resulted in orifice flow conditions at the bridge. Contraction scour at bridges with orifice flow is best estimated by use of the Chang pressureflow scour equation (oral communication, J. Sterling Jones, October 4, 1996). Thus, contraction scour depths were computed by use of the Chang equation (Richardson and others, 1995, P. 145-146). Results from the Chang equation are shown in Figure 8 and tables 1 and 2. The results of Laursen's clear-water contraction scour equation (Richardson, 1995, p. 32, equation 20) also were computed and are provided in appendix F. The streambed armoring depths computed suggest that armoring will not limit the depth of contraction scour.

Abutment scour was computed by use of the Froehlich equation (Richardson and others, 1995, p. 48, equation 28). Variables for the Froehlich equation include the Froude number of the flow approaching the embankments, the length of the embankment blocking flow, and the depth of flow approaching the embankment less any roadway overtopping. 


\section{Scour Results}

100-yr discharge 500-yr discharge

Incipient

Contraction scour:

(Scour depths in feet)

Main channel

Live-bed scour

Clear-water scour

Depth to armoring

Left overbank

Right overbank
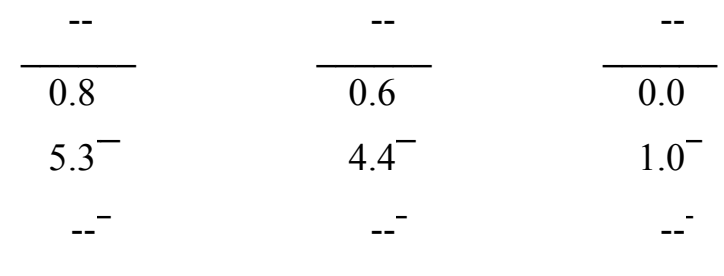

$4.4^{-}$

$1.0^{-}$

overtopping

discharge

Local scour:

Abutment scour

8.3

9.3

7.4

Left abutment

8.0-

$6.1-$

4.2-

Right abutment

Pier scour

Pier 1

Pier 2

Pier 3

Abutments:

Left abutment

Right abutment

Piers:

Pier 1

Pier 2

\section{Riprap Sizing}

Incipient overtopping 100-yr discharge 500-yrdischarge discharge

\begin{tabular}{ccc} 
& $\left(D_{50}\right.$ in feet $)$ & \\
1.5 & 1.4 & 0.8 \\
1.5 & 1.4 & 0.8 \\
-- & -- & -- \\
-- & -- & -- \\
-- & -- & -- \\
\hline
\end{tabular}




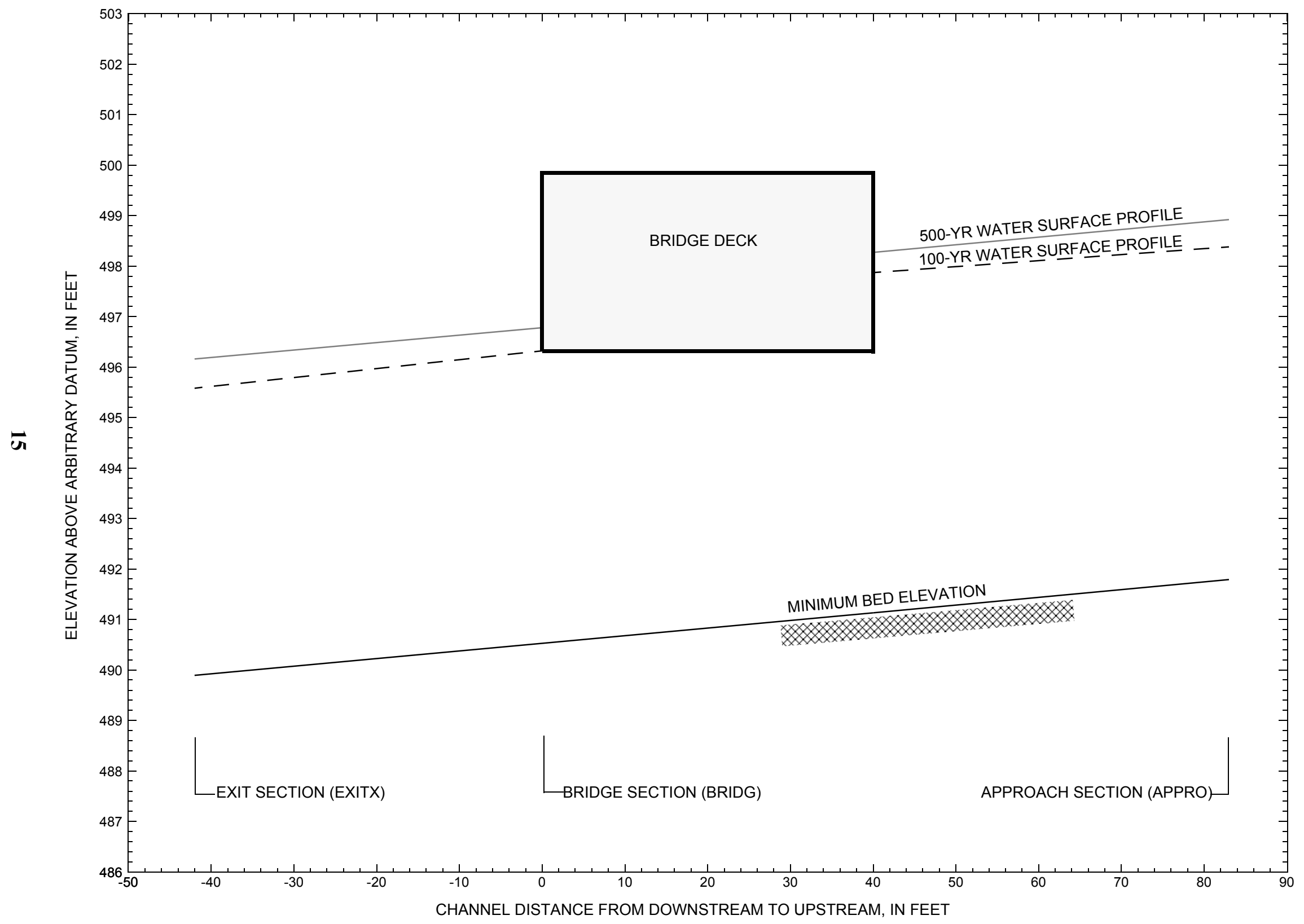

Figure 7. Water-surface profiles for the 100- and 500-yr discharges at structure STAMVT01000002 on State Route 100, crossing Roaring Brook, Stamford, Vermont. 


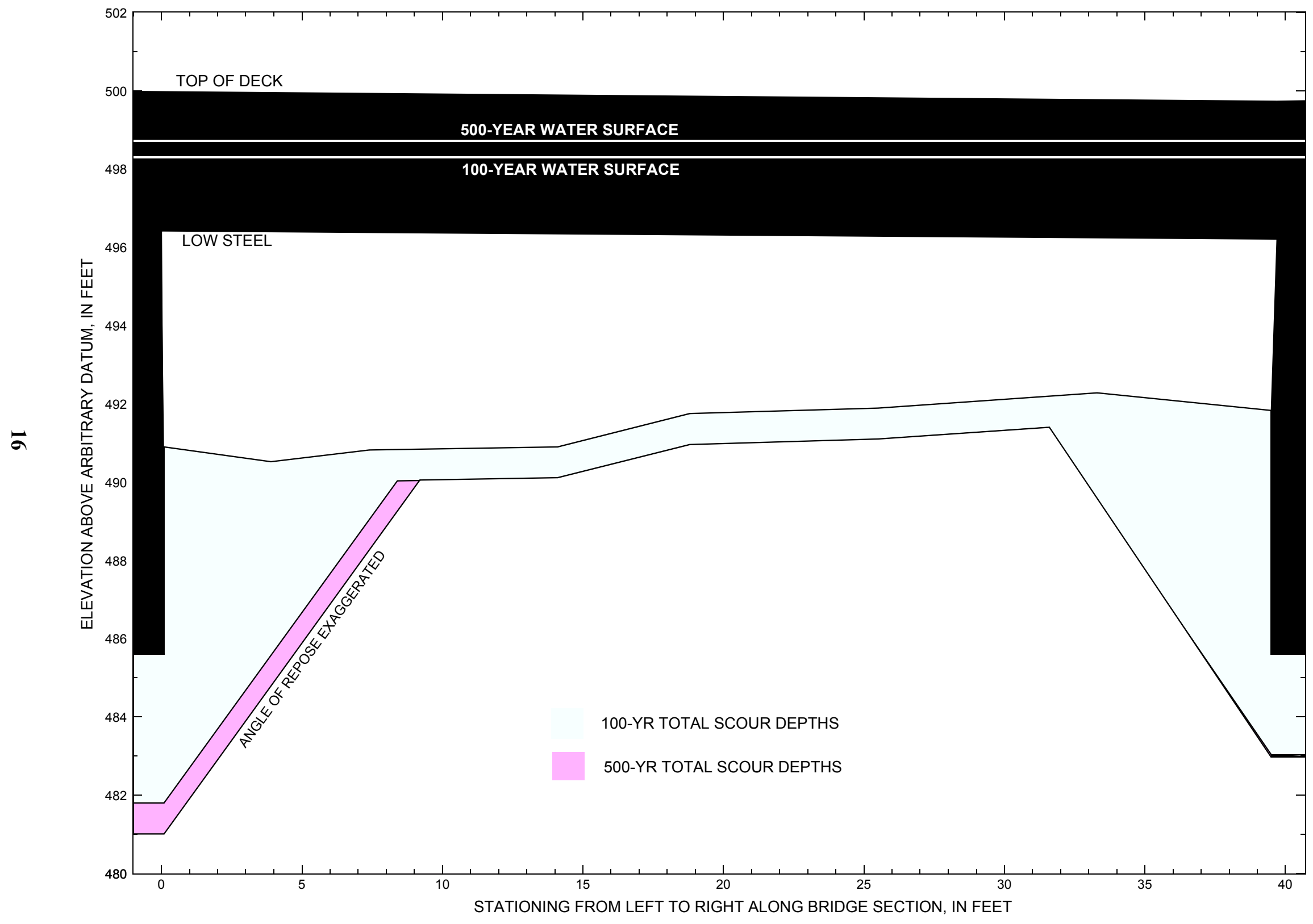

Figure 8. Scour elevations for the 100-yr and 500-yr discharges at structure STAMVT01000002 on State Route 100, crossing Roaring Brook, Stamford, Vermont. 
Table 1. Remaining footing/pile depth at abutments for the 100-year discharge at structure STAMVT01000002 on State Route 100, crossing Roaring Brook, Stamford, Vermont.

[VTAOT, Vermont Agency of Transportation; --,no data]

\begin{tabular}{|c|c|c|c|c|c|c|c|c|c|c|c|}
\hline Description & Station $^{1}$ & $\begin{array}{l}\text { VTAOT } \\
\text { minimum } \\
\text { bridge seat } \\
\text { elevation } \\
\text { (feet) }\end{array}$ & $\begin{array}{l}\text { Surveyed } \\
\text { minimum } \\
\text { low-chord } \\
\text { elevation } \\
\text { (feet) }\end{array}$ & $\begin{array}{l}\text { Bottom of } \\
\text { footing } \\
\text { elevation }{ }^{2} \\
\text { (feet) }\end{array}$ & $\begin{array}{c}\text { Channel } \\
\text { elevation at } \\
\text { abutment/ } \\
\text { pier }^{2} \\
\text { (feet) }\end{array}$ & $\begin{array}{l}\text { Contraction } \\
\text { scour depth } \\
\text { (feet) }\end{array}$ & $\begin{array}{c}\text { Abutment } \\
\text { scour } \\
\text { depth } \\
\text { (feet) }\end{array}$ & $\begin{array}{l}\text { Pier } \\
\text { scour } \\
\text { depth } \\
\text { (feet) }\end{array}$ & $\begin{array}{l}\text { Depth of } \\
\text { total scour } \\
\text { (feet) }\end{array}$ & $\begin{array}{c}\text { Elevation of } \\
\text { scour }^{2} \\
\text { (feet) }\end{array}$ & $\begin{array}{c}\text { Remaining } \\
\text { footing/pile } \\
\text { depth } \\
\text { (feet) }\end{array}$ \\
\hline \multicolumn{12}{|c|}{100 -yr. discharge is 2,450 cubic-feet per second } \\
\hline Left abutment & 0.0 & 1131.2 & 496.5 & 485.6 & 490.9 & 0.8 & 8.3 & -- & 9.1 & 481.8 & -3.8 \\
\hline Right abutment & 39.7 & 1130.8 & 496.2 & 485.6 & 491.8 & 0.8 & 8.0 & -- & 8.8 & 483.0 & -2.6 \\
\hline
\end{tabular}

1.Measured along the face of the most constricting side of the bridge.

2.Arbitrary datum for this study.

Table 2. Remaining footing/pile depth at abutments for the 500-year discharge at structure STAMVT01000002 on State Route 100, crossing Roaring Brook, Stamford, Vermont.

[VTAOT, Vermont Agency of Transportation; --, no data]

\begin{tabular}{|c|c|c|c|c|c|c|c|c|c|c|c|}
\hline Description & Station $^{1}$ & $\begin{array}{l}\text { VTAOT } \\
\text { minimum } \\
\text { bridge seat } \\
\text { elevation } \\
\text { (feet) }\end{array}$ & $\begin{array}{l}\text { Surveyed } \\
\text { minimum } \\
\text { low-chord } \\
\text { elevation }{ }^{2} \\
\text { (feet) }\end{array}$ & $\begin{array}{c}\text { Bottom of } \\
\text { footing } \\
\text { elevation } \\
\text { (feet) }\end{array}$ & $\begin{array}{c}\text { Channel } \\
\text { elevation at } \\
\text { abutment/ } \\
\text { pier }^{2} \\
\text { (feet) }\end{array}$ & $\begin{array}{l}\text { Contraction } \\
\text { scour depth } \\
\text { (feet) }\end{array}$ & $\begin{array}{l}\text { Abutment } \\
\text { scour } \\
\text { depth } \\
\text { (feet) }\end{array}$ & $\begin{array}{l}\text { Pier } \\
\text { scour } \\
\text { depth } \\
\text { (feet) }\end{array}$ & $\begin{array}{l}\text { Depth of } \\
\text { total scour } \\
\text { (feet) }\end{array}$ & $\begin{array}{c}\text { Elevation of } \\
\text { scour }^{2} \\
\text { (feet) }\end{array}$ & $\begin{array}{c}\text { Remaining } \\
\text { footing/pile } \\
\text { depth } \\
\text { (feet) }\end{array}$ \\
\hline \multicolumn{12}{|c|}{500 -yr. discharge is 3,400 cubic-feet per second } \\
\hline Left abutment & 0.0 & 1131.2 & 496.5 & 485.6 & 490.9 & 0.6 & 9.3 & -- & 9.9 & 481.0 & -4.6 \\
\hline Right abutment & 39.7 & 1130.8 & 496.2 & 485.6 & 491.8 & 0.6 & 6.1 & -- & 6.7 & 485.1 & -0.5 \\
\hline
\end{tabular}

1.Measured along the face of the most constricting side of the bridge.

2.Arbitrary datum for this study. 


\section{SELECTED REFERENCES}

Arcement, G.J., Jr., and Schneider, V.R., 1989, Guide for selecting Manning's roughness coefficients for natural channels and flood plains: U.S. Geological Survey Water-Supply Paper 2339, 38 p.

Barnes, H.H., Jr., 1967, Roughness characteristics of natural channels: U.S. Geological Survey Water-Supply Paper 1849,213 p.

Benson, M. A., 1962, Factors Influencing the Occurrence of Floods in a Humid Region of Diverse Terrain: U.S. Geological Survey WaterSupply Paper 1580-B, 64 p.

Brown, S.A. and Clyde, E.S., 1989, Design of riprap revetment: Federal Highway Administration Hydraulic Engineering Circular No. 11, Publication FHWA-IP-89-016, 156 p.

Federal Highway Administration, 1983, Runoff estimates for small watersheds and development of sound design: Federal Highway Administration Report FHWA-RD-77-158

Federal Emergency Management Agency, 1978, Flood Insurance Study, Town of Stamford, Bennington County, Vermont: Washington, D.C., January 1978.

Froehlich, D.C., 1989, Local scour at bridge abutments in Ports, M.A., ed., Hydraulic Engineering--Proceedings of the 1989 National Conference on Hydraulic Engineering: New York, American Society of Civil Engineers, p. 13-18.

Hayes, D.C.,1993, Site selection and collection of bridge-scour data in Delaware, Maryland, and Virginia: U.S. Geological Survey WaterResources Investigation Report 93-4017, 23 p.

Johnson, C.G. and Tasker, G.D.,1974, Progress report on flood magnitude and frequency of Vermont streams: U.S. Geological Survey OpenFile Report 74-130, 37 p.

Lagasse, P.F., Schall, J.D., Johnson, F., Richardson, E.V., Chang, F., 1995, Stream Stability at Highway Structures: Federal Highway Administration Hydraulic Engineering Circular No. 20, Publication FHWA-IP-90-014, 144 p.

Laursen, E.M., 1960, Scour at bridge crossings: Journal of the Hydraulics Division, American Society of Civil Engineers, v. 86, no. HY2, p. 39-53.

Potter, W. D., 1957a, Peak rates of runoff in the Adirondack, White Mountains, and Maine woods area, Bureau of Public Roads

Potter, W. D., 1957b, Peak rates of runoff in the New England Hill and Lowland area, Bureau of Public Roads

Richardson, E.V. and Davis, S.R., 1995, Evaluating scour at bridges: Federal Highway Administration Hydraulic Engineering Circular No. 18, Publication FHWA-IP-90-017, 204 p.

Richardson, E.V., Simons, D.B., and Julien, P.Y., 1990, Highways in the river environment: Federal Highway Administration Publication FHWA-HI-90-016.

Ritter, D.F., 1984, Process Geomorphology: W.C. Brown Co., Debuque, Iowa, 603 p.

Shearman, J.O., 1990, User's manual for WSPRO--a computer model for water surface profile computations: Federal Highway Administration Publication FHWA-IP-89-027, 187 p.

Shearman, J.O., Kirby, W.H., Schneider, V.R., and Flippo, H.N., 1986, Bridge waterways analysis model; research report: Federal Highway Administration Publication FHWA-RD-86-108, 112 p.

Talbot, A.N., 1887, The determination of water-way for bridges and culverts.

U.S. Department of Transportation, 1993, Stream stability and scour at highway bridges, Participant Workbook: Federal Highway Administration Publication FHWA HI-91-011.

U.S. Geological Survey, 1954, Stamford, Vermont 7.5 Minute Series quadrangle map: U.S. Geological Survey Topographic Maps, Aerial photography 1942 and 1951; Contour interval, 20 feet; Scale 1:24,000. 


\section{APPENDIX A: \\ WSPRO INPUT FILE}




\section{WSPRO INPUT FILE}

GR

GR

GR

GR

GR

$N$

SA

*

*

BR

GR

GR

GR

CD

$\mathrm{N}$

$\mathrm{XR}$

GR

GR

*

*

GR

GR

GR

*

*

*

$\mathrm{N}$

SA

U.S. Geological Survey WSPRO Input File stam002.wsp Hydraulic analysis for structure STAMVT01000002 Date: 06-JAN-97 State Route 100 Crossing of Roaring Brook, Stamford, VT

EMB

* $\quad$ 0.002

$\begin{array}{lllllllllllllllllllll}6 & 29 & 30 & 552 & 553 & 551 & 5 & 16 & 17 & 13 & 3 & * & 15 & 14 & 23 & 21 & 11 & 12 & 4 & 7 & 3\end{array}$

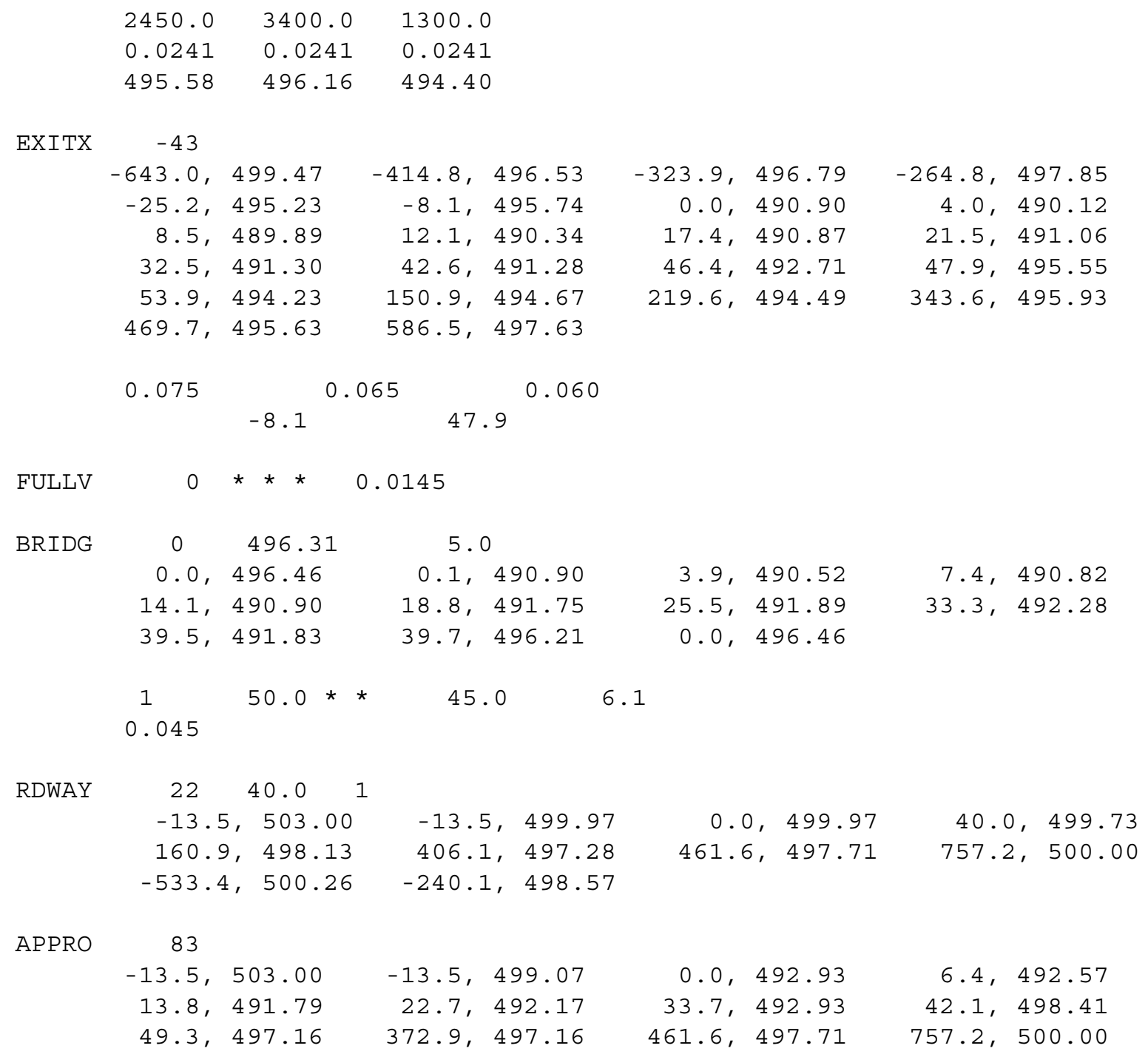




\section{APPENDIX B: \\ WSPRO OUTPUT FILE}


WSPRO OUTPUT FILE

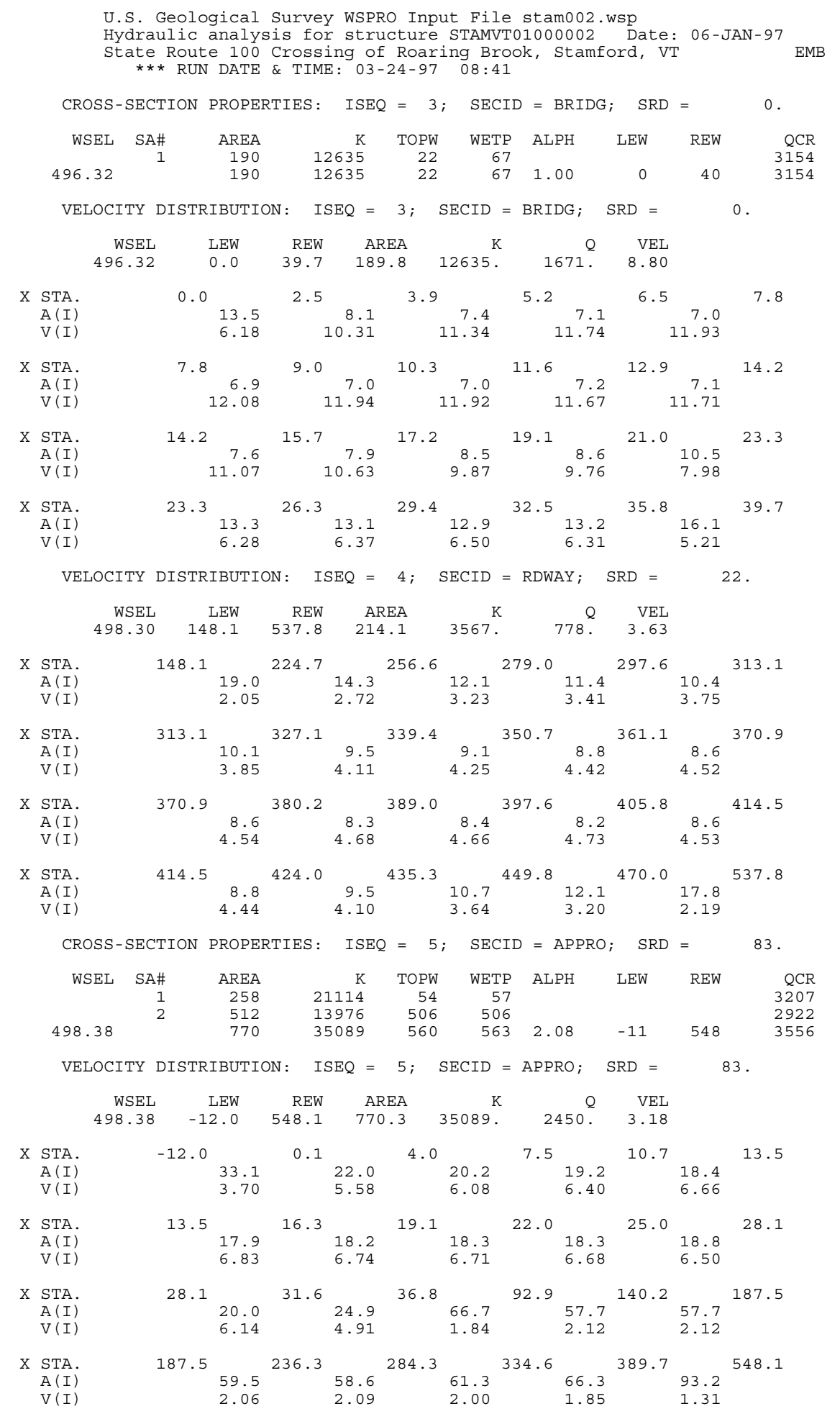


WSPRO OUTPUT FILE (continued)

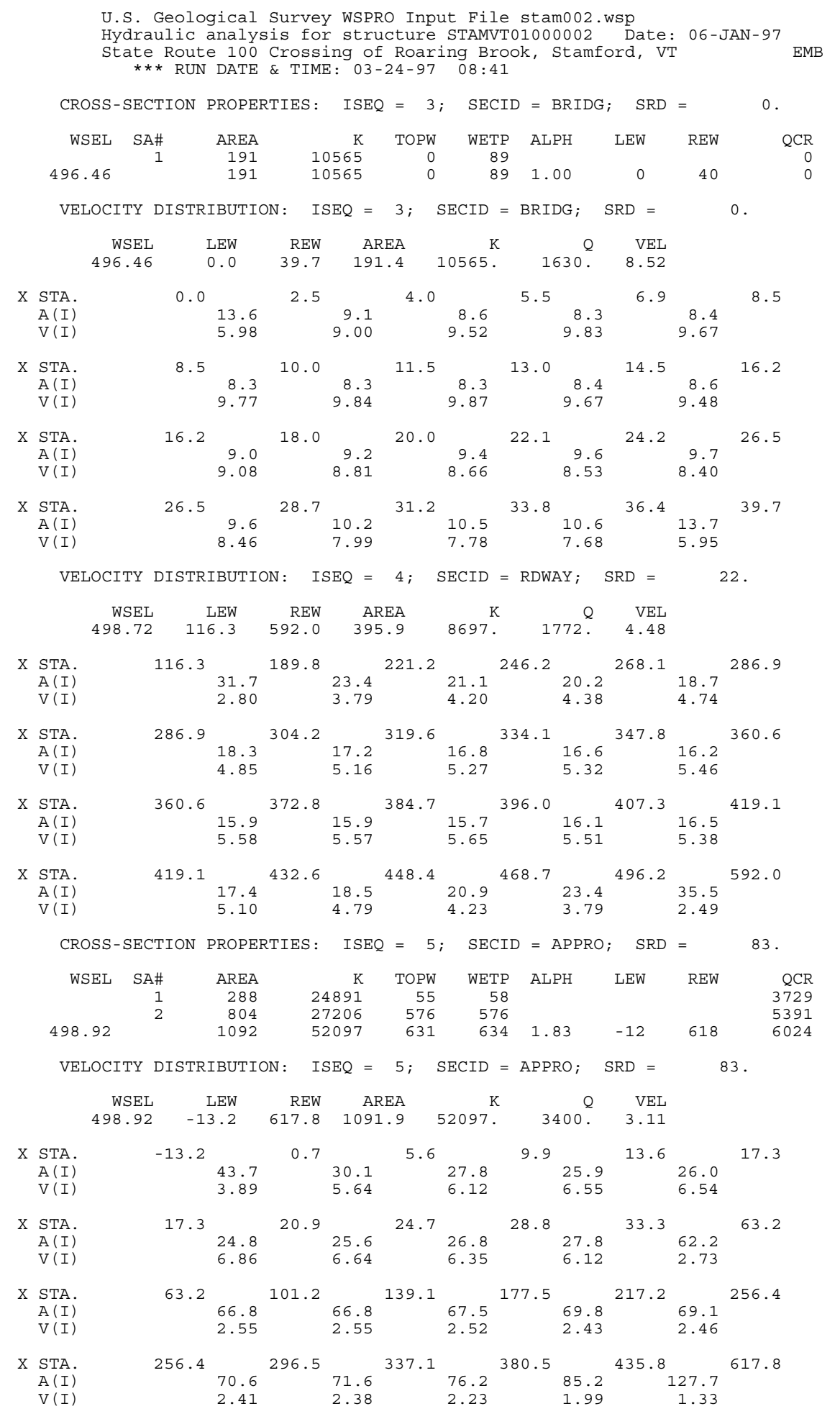


WSPRO OUTPUT FILE (continued)

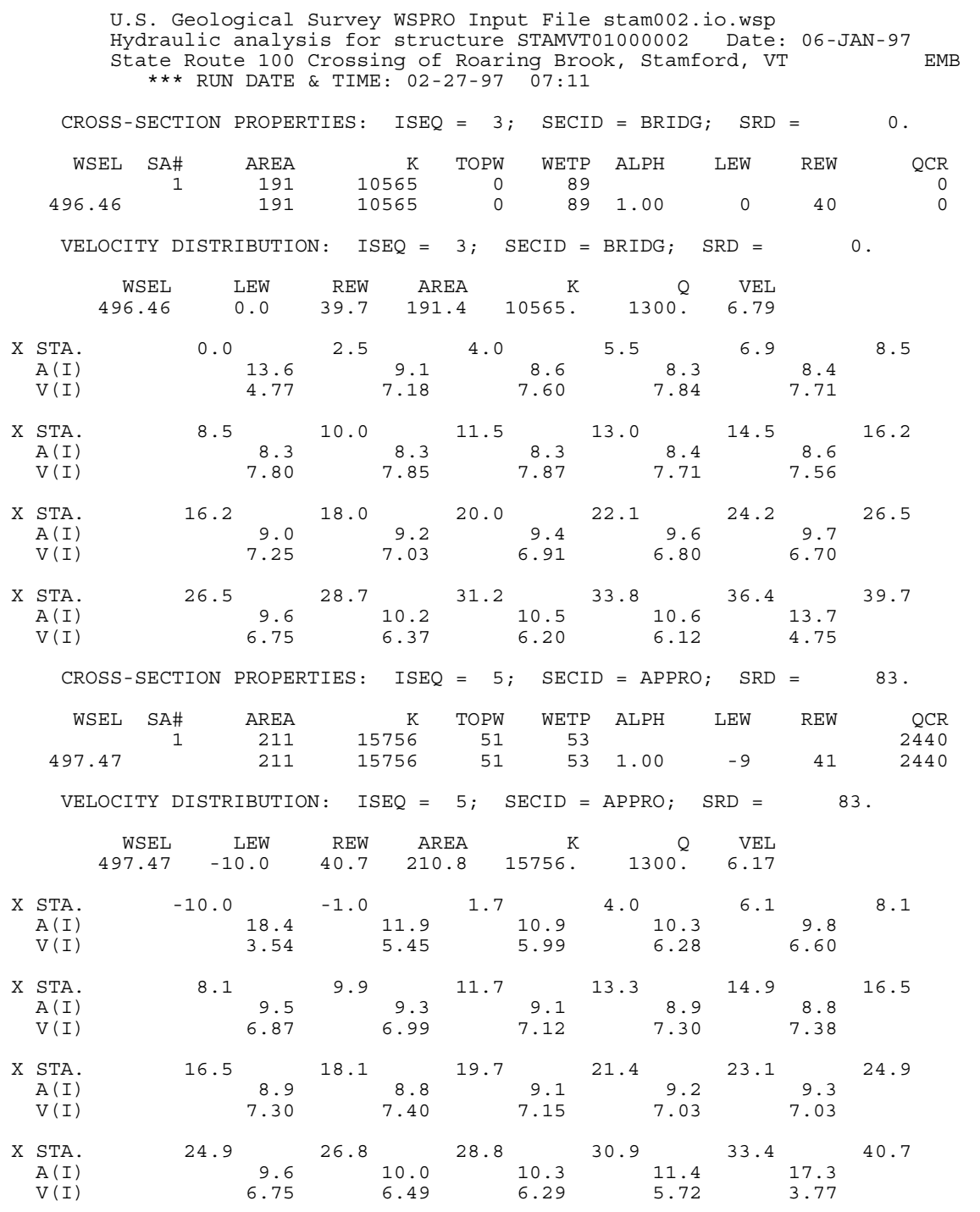




\section{WSPRO OUTPUT FILE (continued)}

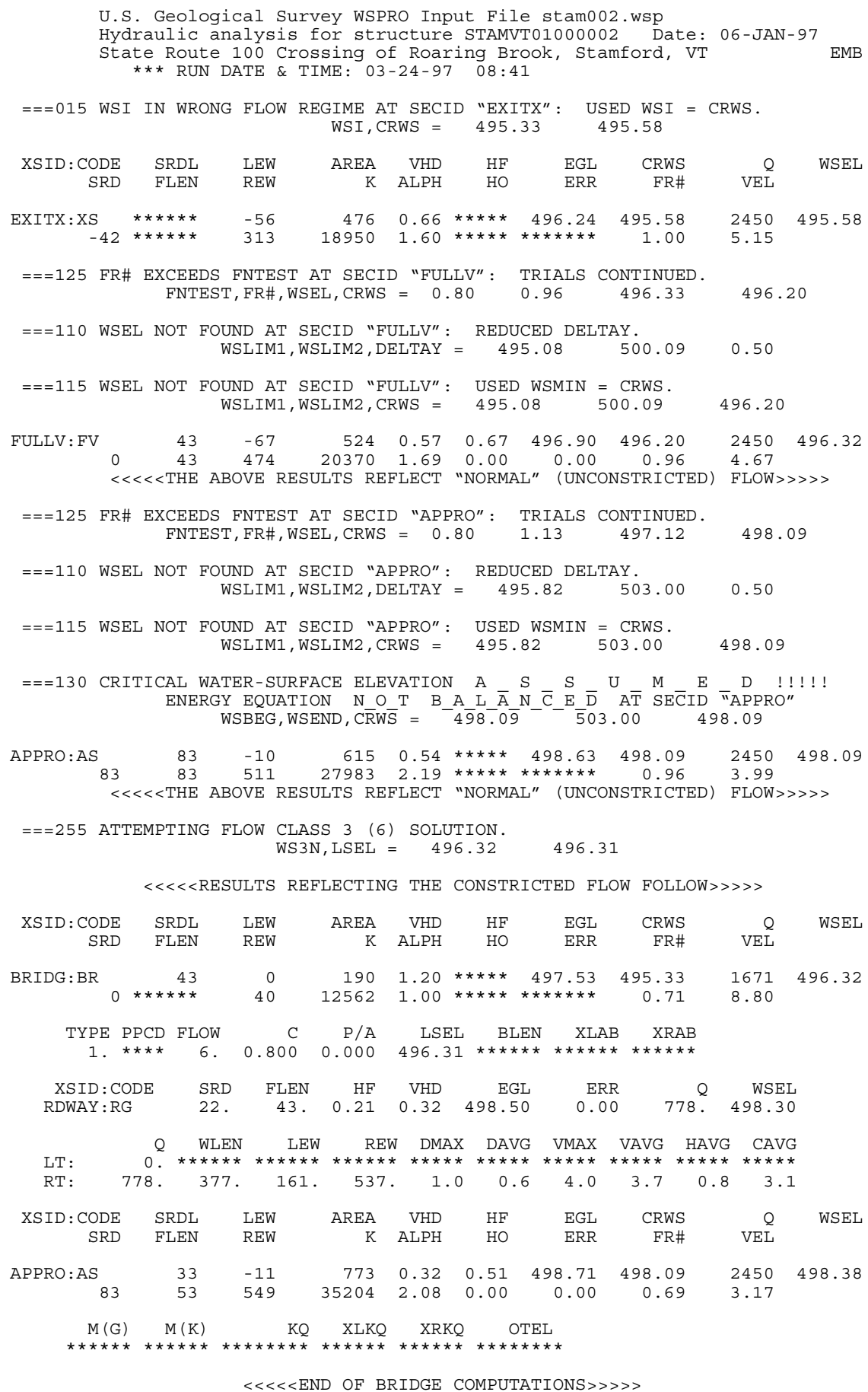

FIRST USER DEFINED TABLE.

\begin{tabular}{|c|c|c|c|c|c|c|c|c|}
\hline XSID: CODE & SRD & LEW & REW & 0 & $\mathrm{~K}$ & AREA & VEL & WSEL \\
\hline EXITX:XS & -43 . & -57. & 313. & 2450 . & 18950. & 476. & 5.15 & 495.58 \\
\hline FULLV: FV & 0. & -68. & 474 . & 2450 . & 20370 . & 524. & 4.67 & 496.32 \\
\hline BRIDG : BR & 0 & 0 . & 40. & 1671. & 12562 & 190. & 8.80 & 496.32 \\
\hline RDWAY : RG & 22. & $\star \star \star \star \star *$ & 0. & 778 . & 0 . & $* * * * *$ & 1.00 & 498.30 \\
\hline APPRO: AS & 83. & -12 . & 549. & 2450 . & 35204. & 773. & 3.17 & 498.38 \\
\hline
\end{tabular}

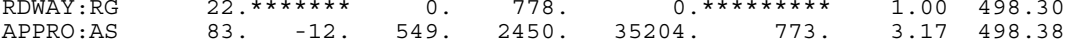

XSID: CODE XLKQ XRKQ KQ

APPRO: AS $* * * * * * * * * * * * * * * * * * * * * * *$

SECOND USER DEFINED TABLE.

$\begin{array}{lcrrrrrrrr}\text { XSID : CODE } & \text { CRWS } & \text { FR\# } & \text { YMIN } & \text { YMAX } & \text { HF } & \text { HO } & \text { VHD } & \text { EGL } & \text { WSEL } \\ \text { EXITX:XS } & 495.58 & 1.00 & 489.89 & 499.47 * * * * * * * * * * * & 0.66 & 496.24 & 495.58 \\ \text { FULLV:FV } & 496.20 & 0.96 & 490.51 & 500.09 & 0.67 & 0.00 & 0.57 & 496.90 & 496.32 \\ \text { BRIDG :BR } & 495.33 & 0.71 & 490.52 & 496.46 * * * * * * * * * * & 1.20 & 497.53 & 496.32 \\ \text { RDWAY:RG } & * * * * * * * * * * * * * * & 497.28 & 503.00 & 0.21 * * * * * & 0.32 & 498.50 & 498.30 \\ \text { APPRO:AS } & 498.09 & 0.69 & 491.79 & 503.00 & 0.51 & 0.00 & 0.32 & 498.71 & 498.38\end{array}$




\section{WSPRO OUTPUT FILE (continued)}

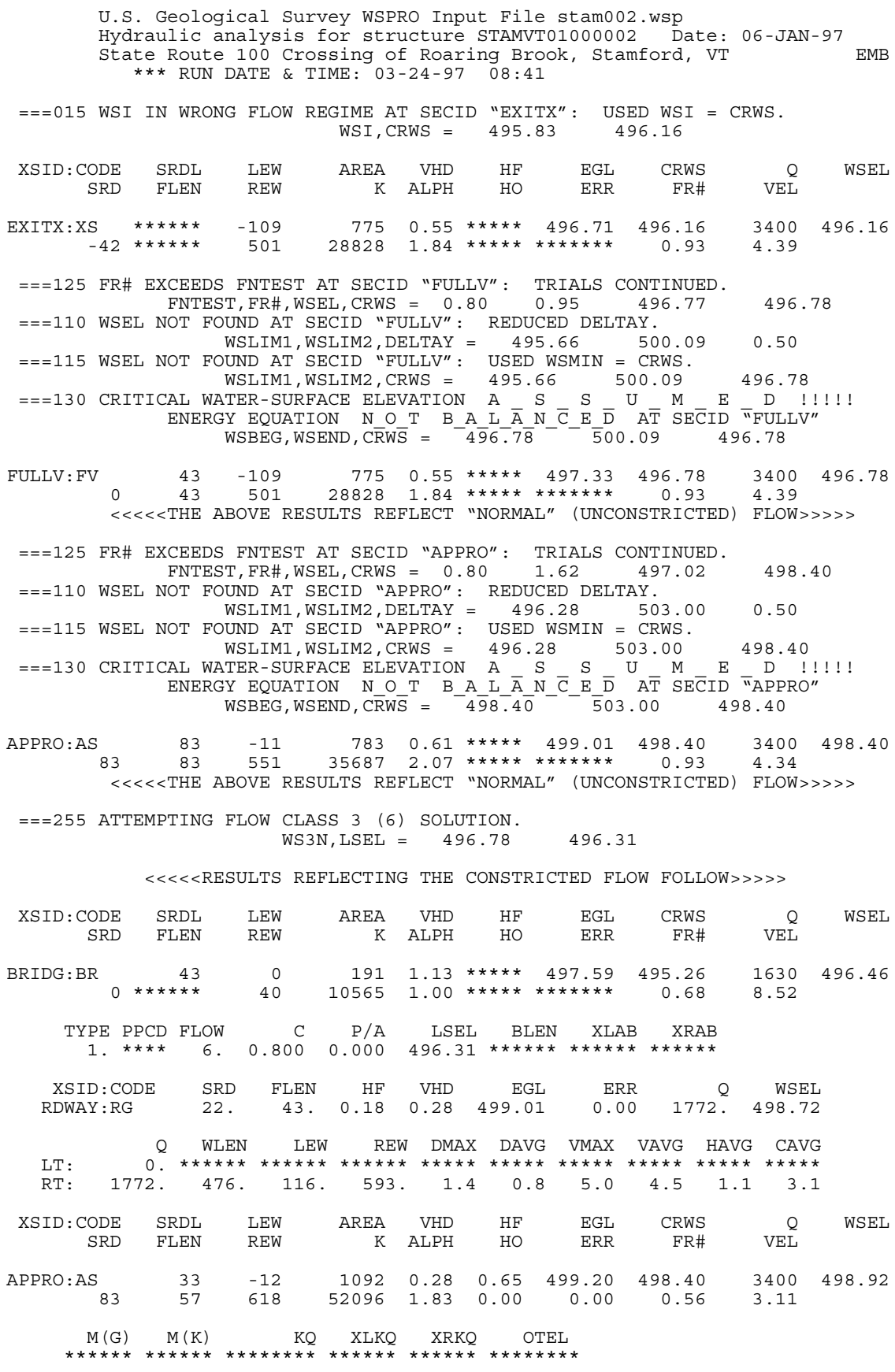

$<<<<$ END OF BRIDGE COMPUTATIONS $>>>>>$

FIRST USER DEFINED TABLE.

\begin{tabular}{|c|c|c|c|c|c|c|c|c|}
\hline XSID : CODE & SRD & LEW & REW & $\mathrm{Q}$ & $\mathrm{K}$ & AREA & VEL & WSEL \\
\hline EXITX:XS & -43. & -110. & 501. & 3400 . & 28828 . & 775. & 4.39 & 496.16 \\
\hline FULLV : FV & 0 & -110. & 501. & 3400 . & 28828. & 775. & 4.39 & 496.78 \\
\hline BRIDG : BR & 0 & 0 & 40. & 1630. & 10565. & 191. & 8.52 & 496.4 \\
\hline RDWAY : RG & 22 . & $* * * * *$ & 0. & 1772 . & 0 & $* \star * * * *$ & 1.00 & 498.7 \\
\hline APPRO:AS & 83. & -13 & 618. & 3400 . & 52096 . & 1092. & 3.11 & 498.92 \\
\hline
\end{tabular}

XSID:CODE XLKQ XRKQ KQ

APPRO: AS $* * * * * * * * * * * * * * * * * * * * * * *$

SECOND USER DEFINED TABLE.

\begin{tabular}{|c|c|c|c|c|c|c|c|c|c|}
\hline XSID: CODE & CRWS & FR\# & YMIN & YMAX & $\mathrm{HF}$ & $\mathrm{HO}$ & VHD & EGL & WSEL \\
\hline EXITX:XS & 496.16 & 0.93 & 489.89 & 499.47 ** & $* * * \star * *$ & $\star * *$ & 0.55 & 496.71 & 496.16 \\
\hline FULLV : FV & 496.78 & 0.93 & 490.51 & $500.09 * *$ & $\star * \star \star \star \star \star \star *$ & $\star \star \star \star \star *$ & 0.55 & 497.33 & 496.78 \\
\hline BRI & 495.26 & 0.68 & .52 & $6 * *$ & $\star * \star \star \star \star \star \star *$ & 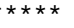 & 1.13 & 497.59 & 496 \\
\hline RDWAY : RG & $\star \star \star \star \star \star * \star * \star * *$ & $* * * * *$ & 497.28 & 503.00 & $0.18 * *$ & $* \star \star * *$ & 0.28 & 499.01 & 498.72 \\
\hline APPRO : AS & 498.40 & 0.56 & 491.79 & 503.00 & 0.65 & 0.00 & 0.28 & 499.20 & 498.92 \\
\hline
\end{tabular}


WSPRO OUTPUT FILE (continued)

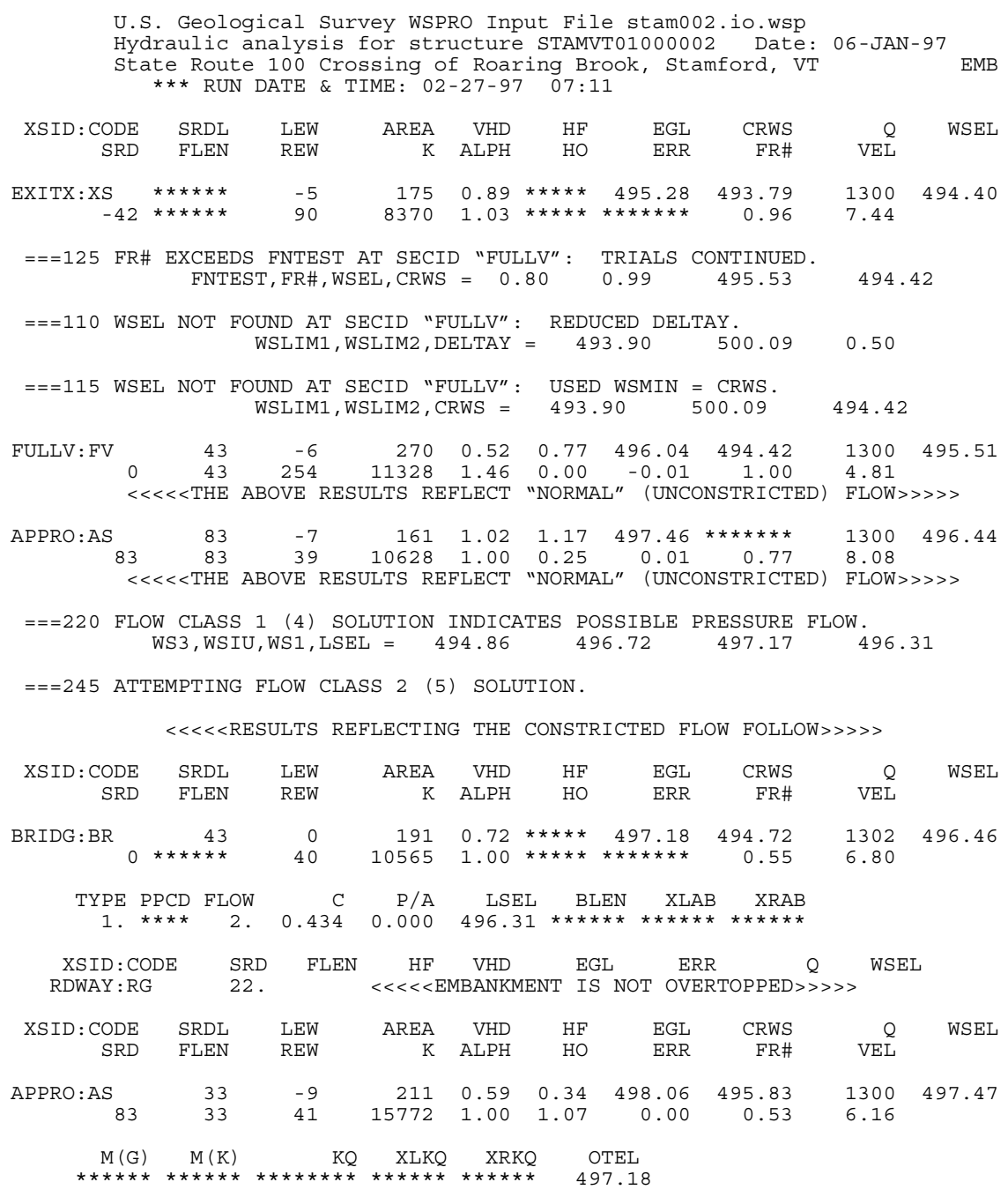

<<<< END OF BRIDGE COMPUTATIONS $>>>>>$

FIRST USER DEFINED TABLE.

\begin{tabular}{|c|c|c|c|c|c|c|c|c|}
\hline XSID : CODE & SRD & LEW & REW & Q & $\mathrm{K}$ & AREA & VEL & WSEL \\
\hline EXITX:XS & -43 & -6 & 90. & 1300. & 8370. & 175. & 7.44 & 494.40 \\
\hline FULLV : FV & 0. & -7. & 254 . & 1300 . & 11328 . & 270 . & 4.81 & 495.51 \\
\hline BRIDG : BR & 0 . & 0 . & 40. & 1302. & 10565. & 191. & 6.80 & 496.46 \\
\hline RDWAY : RG & 22 . & $* * * * *$ & 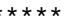 & 0 & 0 & 0 . & $1.00 *$ & 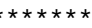 \\
\hline APPRO: AS & 83. & -10 & 41. & 1300. & 15772 . & 211. & 6.16 & 497.47 \\
\hline XSID : CODE & XLKQ & XRKQ & & & & & & \\
\hline
\end{tabular}

SECOND USER DEFINED TABLE.

\begin{tabular}{|c|c|c|c|c|c|c|c|c|c|}
\hline XSID : CODE & CRWS & FR\# & YMIN & YMAX & $\mathrm{HF}$ & $\mathrm{HO}$ & VHD & EGL & WSEL \\
\hline EXITX:XS & 493.79 & 0.96 & 489.89 & 499.47 * & $\star * \star * * *$ & $\star \star \star * \star *$ & 0.89 & 495.28 & 494.40 \\
\hline FULLV : FV & 494.42 & 1.00 & 490.51 & 500.09 & 0.77 & 0.00 & 0.52 & 496.04 & 495.51 \\
\hline BRIDG : BR & 494.72 & 0.55 & 490.52 & $496.46 *$ & 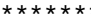 & 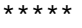 & 0.72 & 497.18 & 496.46 \\
\hline RDWAY : RG & 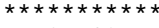 & 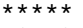 & 497.28 & $503.00 *$ & 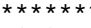 & 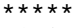 & 0.59 & $497.77 *$ & 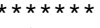 \\
\hline APPRO : AS & 495.83 & 0.53 & 491.79 & 503.00 & 0.34 & 1.07 & 0.59 & 498.06 & 497.47 \\
\hline ER & & & & & & & & & \\
\hline
\end{tabular}




\section{APPENDIX C:}

\section{BED-MATERIAL PARTICAL-SIZE DISTRIBUTION}




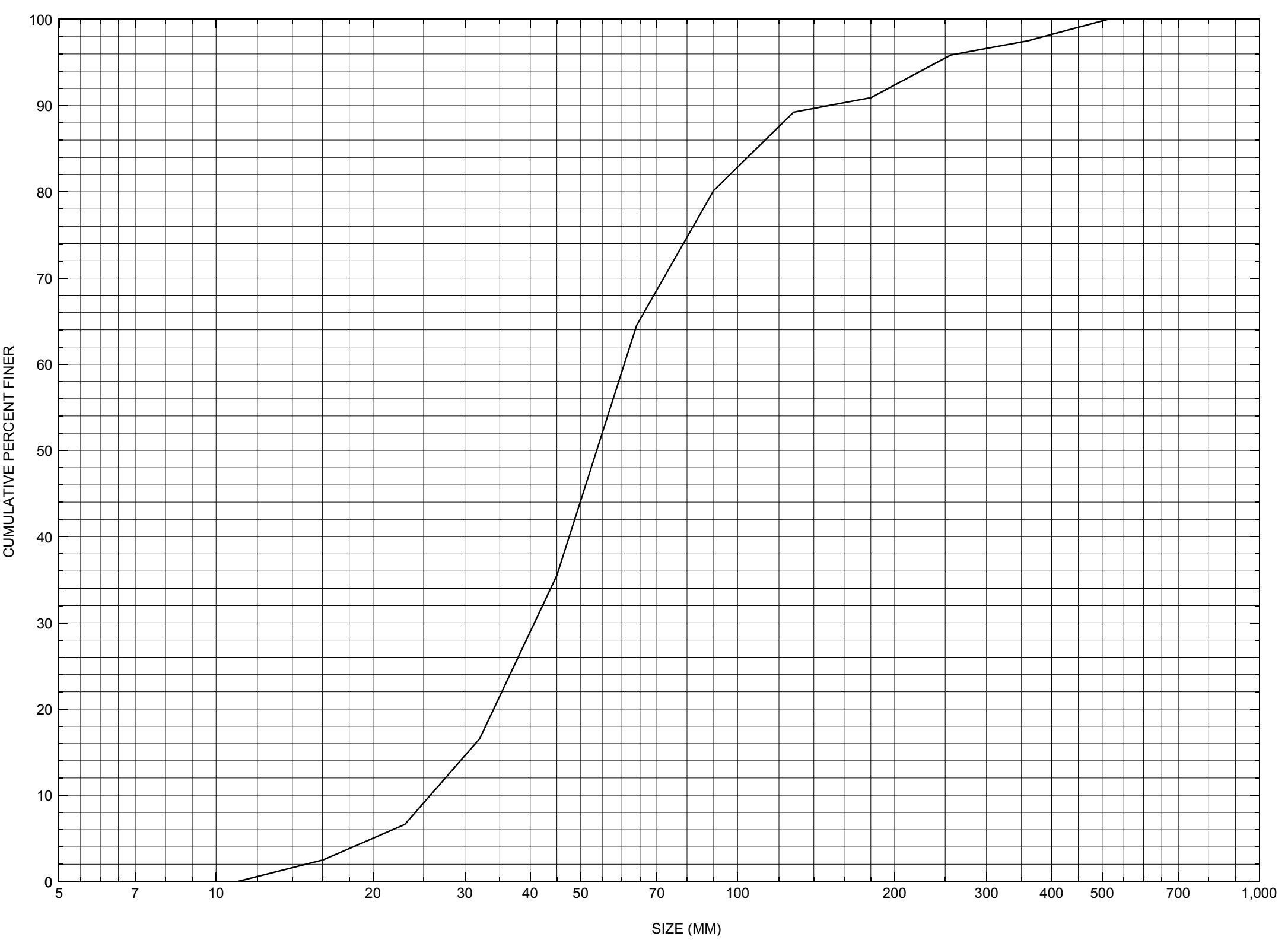

Appendix C. Bed material particle-size distribution for a pebble count in the channel approach of structure STAMVT01000002, in Stamford, Vermont. 


\section{APPENDIX D: \\ HISTORICAL DATA FORM}




\section{Structure Number STAMVT01000002}

\section{General Location Descriptive}

Data collected by (First Initial, Full last name) $\underline{\mathbf{L}}$. Medalie

Date $(M M / D D / Y Y) \_09 / \underline{28} / \underline{95}$

Highway District Number (I - 2; nn) 01

Town (FIPS place code; I - 4; nnnnn) $\mathbf{6 9 7 7 5}$

Waterway (I - 6) Roaring Brook

Route Number VT100

Topographic Map Stamford

Latitude (I - 16; nnnn.n) $\mathbf{4 2 4 5 5}$
County (FIPS county code; I - 3; nnn)

Mile marker (I - 11; nnn.nnn) $\underline{\mathbf{0 0 1 1 6 0}}$

Road Name (I - 7): -

Vicinity (I - 9) 1.2 MI N MA STATE LINE

Hydrologic Unit Code: $\underline{\mathbf{0 2 0 2 0 0 0 3}}$

Longitude (i - 17; nnnnn.n) 73041

\section{Select Federal Inventory Codes}

FHWA Structure Number $(I$ - 8) $\mathbf{2 0 0 1 0 2 0 0 0 2 0 2 1 4}$

Maintenance responsibility $(I-21 ; n n) \quad \mathbf{0 1} \quad$ Maximum span length $(I-48 ; n n n n) \underline{\mathbf{0 0 4 2}}$

Year built (I - 27; YYYY) 1963

Structure length (I - 49; nnnnnn) $\underline{\mathbf{0 0 0 0 4 4}}$

Average daily traffic, ADT (I - 29; nnnnnn) 001670

Deck Width (I - 52; nn.n) $\mathbf{4 0 0}$

Year of ADT (I - 30; YY) $\mathbf{9 2}$

Channel \& Protection $(I-61 ; n) \underline{\mathbf{6}}$

Opening skew to Roadway (I - 34; nn)

Waterway adequacy $(I-71 ; n) \underline{\mathbf{5}}$

Operational status $(I-41 ; X) \quad \mathbf{A}$

Underwater Inspection Frequency $(I-92 B ; X Y Y) \_\mathbf{N}$

Structure type (I- 43; nnn) $\mathbf{3 0 2}$

Year Reconstructed (I - 106) $\mathbf{0 0 0 0}$

Approach span structure type (I - 44; nnn) $\mathbf{0 0 0}$

Clear span (nnn.n ft) $\mathbf{3 1}$

Number of spans (I - 45; nnn) $\underline{\mathbf{0 0 1}}$

Vertical clearance from streambed (nnn.n ft) $\underline{7}$

Number of approach spans (I - 46; nnnn) $\underline{\mathbf{0 0 0 0}}$ Waterway of full opening $\left(n n n . n \mathrm{ft}^{2}\right) \underline{\mathbf{2 1 7}}$

Comments:

According to the structural inspection report dated $8 / 24 / 93$, the structure is a single span rolled beam bridge. The right abutment wall has some minor staining and cracking and the wingwalls have some minor cracking and scaling. The bridge seat of the left abutment has some debris. The left abutment concrete is in good condition, except some minor cracking and scaling along the flow line. The left abutment wingwalls are in good condition with only minor cracking and scaling. The channel is straight through structure. Currently, flow is along the left abutment side of the channel, and there is a sand, stone and cobble build-up along the right abutment side of the channel. (Continued, page 31) 


\section{Bridge Hydrologic Data}

Is there hydrologic data available? $\underline{\mathbf{N}}$ if No, type ctrl-n $h \quad$ VTAOT Drainage area $\left(m i^{2}\right)$ : -

Terrain character:

Stream character \& type: -

Streambed material:

Discharge Data (cfs):

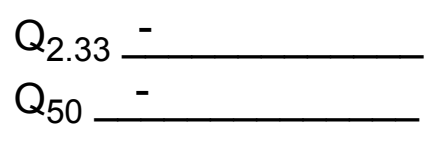

Record flood date $(M M / D D / Y Y):-{ }^{\prime}-$
Estimated Discharge $(c f s):-$

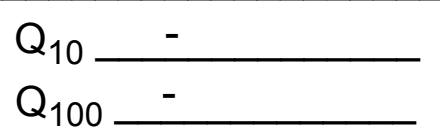

$\mathrm{Q}_{25}$

Water surface elevation $(f t):-$ $(\mathrm{ft} / \mathrm{s}):$

Ice conditions (Heavy, Moderate, Light) : -

Debris (Heavy, Moderate, Light):

The stage increases to maximum highwater elevation (Rapidly, Not rapidly):

The stream response is (Flashy, Not flashy):

Describe any significant site conditions upstream or downstream that may influence the stream's stage: -

Watershed storage area (in percent):

The watershed storage area is: - (1-mainly at the headwaters; 2- uniformly distributed; 3-immediatly upstream oi the site)

Water Surface Elevation Estimates for Existing Structure:

\begin{tabular}{|l|l|l|l|l|l|}
\hline Peak discharge frequency & $Q_{2.33}$ & $Q_{10}$ & $Q_{25}$ & $Q_{50}$ & $Q_{100}$ \\
Water surface elevation (ft)) & - & - & - & - & - \\
Velocity (ft/sec) & - & - & - & - & - \\
\hline
\end{tabular}

Long term stream bed changes: -

Is the roadway overtopped below the $\mathrm{Q}_{100}$ ? (Yes, No, Unknown): $\mathbf{U}$ Frequency: -

Relief Elevation $(f t)$ :

Discharge over roadway at $Q_{100}\left(f t^{3} / \mathrm{sec}\right)$ :

Are there other structures nearby? (Yes, No, Unknown): Upstream distance (miles): Town: If No or Unknown, type ctrl-n os Highway No. :Structure No. : Year Built:

Clear span (ft): Clear Height $(f t)$ : Full Waterway $\left(f^{2}\right)$ : 
Downstream distance (miles): Town: Year Built:

Highway No. : Structure No. : Structure Type:

Clear span $(f t):$ Clear Height $(f t)$ : Full Waterway $\left(f^{2}\right)$ :

Comments:

Some minor stream bank erosion and channel scour is noted US. The abutment footings are not exposed. A note dated 3/17/92 in the hydraulic section's folder with a subject of "re: evaluation of ice impact on 3/11/92" states "ice packed in around bearing device at Beam \#1, Abut \#1 (Rabut) - minor scraping of paint on Beam \#1 - no displacement or bending of beams - no apparent scour at abutments, but could not definitely be determined due to ice cover - no cracking or scaling in abutments or wings."

\section{USGS Watershed Data}

Watershed Hydrographic Data

Drainage area (DA)

Watershed storage (ST)

8.26 $\mathrm{mi}^{2}$ Lake and pond area $\mathbf{0}$ $\mathrm{mi}^{2}$

Bridge site elevation 1115 $\mathrm{ft}$ $\%$

Main channel length 5.97 $\mathrm{mi}$

$10 \%$ channel length elevation $\mathbf{1 1 2 5}$ $\mathrm{ft} \quad 85 \%$ channel length elevation 3040 $\mathrm{ft}$

Main channel slope (S)

(S) 427.69 $\mathrm{ft} / \mathrm{mi}$

Watershed Precipitation Data

Average site precipitation in Average headwater precipitation in

Maximum 2yr-24hr precipitation event $(124,2)$ in

Average seasonal snowfall (Sn) $\mathrm{ft}$ 


\section{Bridge Plan Data}

Are plans available? $\mathbf{Y}$ Project Number $\mathbf{S}$ 0102(3) If no, type ctrl-n pl (3)

Low superstructure elevation: USLAB 1131.07 DSLAB 1131.16

Minimum channel bed elevation: 1124.5

Benchmark location description:

Disc on bridge, downstream corner of abutment and right wingwall, elev. 1135.12

Reference Point (MSL, Arbitrary, Other): Unknown D Datum (NAD27, NAD83, Other): Unknown Foundation Type: 1 (1-Spreadfooting; 2-Pile; 3- Gravity; 4-Unknown)

If 1: Footing Thickness $\mathbf{2} \quad$ Footing bottom elevation: $\underline{\mathbf{1 1 2 0 . 5}}$

If 2: Pile Type: ___ (1-Wood; 2-Steel or metal; 3-Concrete) Approximate pile driven length: -

If 3: Footing bottom elevation: -

Is boring information available? $\underline{\mathbf{Y}}$ If no, type ctrl-n bi Number of borings taken: $\underline{4}$

Foundation Material Type: $\mathbf{3}$ (1-regolith, 2-bedrock, 3-unknown)

Briefly describe material at foundation bottom elevation or around piles:

Refusal for the 4 drill-borings varies from 8.75 to 11.5 feet below the surface. Above that is very coarse gravel and boulders.

Comments:

The low superstructure elevations are bridge seat elevations from the bridge plans. 


\section{Cross-sectional Data}

Is cross-sectional data available? $\underline{\mathbf{Y}}$ If no, type ctrl-n xs

Source (FEMA, VTAOT, Other)? FEMA

Comments: The stations and elevations are in feet (NGVD).

\begin{tabular}{|l|l|l|l|l|l|l|l|l|l|l|l|}
\hline Station & $\mathbf{4 1 5 . 5}$ & $\mathbf{4 3 5}$ & $\mathbf{4 5 5 . 5}$ & & & & & & & & \\
\hline Feature & LAB & & RAB & & & & & & & & \\
\hline $\begin{array}{l}\text { Low cord } \\
\text { elevation }\end{array}$ & $\mathbf{1 1 3 1 . 8}$ & $\mathbf{1 1 3 1 . 7}$ & $\mathbf{1 1 3 1 . 6}$ & & & & & & & & \\
\hline $\begin{array}{l}\text { Bed } \\
\text { elevation }\end{array}$ & $\mathbf{1 1 2 7 . 8}$ & $\mathbf{1 1 2 8}$ & $\mathbf{1 1 2 8 . 1}$ & & & & & & & & \\
\hline $\begin{array}{l}\text { Low cord to } \\
\text { bed length }\end{array}$ & $\mathbf{4}$ & $\mathbf{3 . 7}$ & $\mathbf{3 . 5}$ & & & & & & & & \\
\hline Station & & & & & & & & & & & \\
\hline Feature & & & & & & & & & & & \\
\hline $\begin{array}{l}\text { Low cord } \\
\text { elevation }\end{array}$ & & & & & & & & & & & \\
\hline $\begin{array}{l}\text { Bed } \\
\text { elevation }\end{array}$ & & & & & & & & & & & \\
\hline $\begin{array}{l}\text { Low cord to } \\
\text { bed length }\end{array}$ & & & & & & & & & & & \\
\hline
\end{tabular}

Source (FEMA, VTAOT, Other)?

Comments:

\begin{tabular}{|l|l|l|l|l|l|l|l|l|l|l|l|}
\hline Station & & & & & & & & & & & \\
\hline Feature & & & & & & & & & & & \\
\hline $\begin{array}{l}\text { Low cord } \\
\text { elevation }\end{array}$ & & & & & & & & & & & \\
\hline $\begin{array}{l}\text { Bed } \\
\text { elevation }\end{array}$ & & & & & & & & & & & \\
\hline $\begin{array}{l}\text { Low cord to } \\
\text { bed length }\end{array}$ & & & & & & & & & & & \\
\hline Station & & & & & & & & & & & \\
\hline Feature & & & & & & & & & & & \\
\hline $\begin{array}{l}\text { Low cord } \\
\text { elevation }\end{array}$ & & & & & & & & & & & \\
\hline $\begin{array}{l}\text { Bed } \\
\text { elevation }\end{array}$ & & & & & & & & & & & \\
\hline $\begin{array}{l}\text { Low cord to } \\
\text { bed length }\end{array}$ & & & & & & & & & & & \\
\hline
\end{tabular}




\section{APPENDIX E: \\ LEVEL I DATA FORM}




\section{Structure Number STAMVT01000002}

Computerized by: $\underline{\mathbf{R B}}$ Date: $10 / 08 / 96$

Reviewd by: EMB Date: 2/5/97

\section{A. General Location Descriptive}

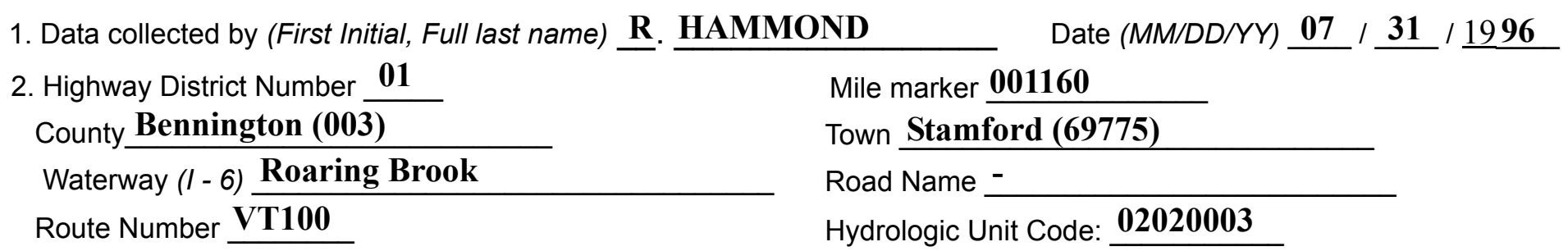

3. Descriptive comments:

Bridge plate reads, "S-0102(3) 1963." Bridge is located 1.2 miles north of the Massachusetts state line and just north of the community of Stamford. Residents call the road Main Street and talked about the channel filling in over the last 10 years and the ice jam of last winter that flooded adjacent yards and basements. 4

\section{B. Bridge Deck Observations}
4. Surface cover... LBUS 2
RBUS 5
LBDS 2
RBDS 2
Overall 2

(2b us,ds,lb,rb: 1- Urban; 2- Suburban; 3- Row crops; 4- Pasture; 5- Shru $b$ - and brushland; 6- Forest; 7- Wetland)
5. Ambient water surface... US $\underline{2}$
UB 2
DS 1
(1- pool; 2- riffle)

6. Bridge structure type 44 (1- single span; 2- multiple span; 3- single arch; 4- multiple arch; 5-cylindrical culvert;

\section{Bridge length 42 (feet)}

\section{Road approach to bridge:}
8. LB $\underline{0}$ RB $\underline{1}$
( 0 even, 1- lower, 2- higher)
9. $L B \_$RB $\underline{0}$
(1- Paved, 2- Not paved)

10. Embankment slope (run / rise in feet / foot):

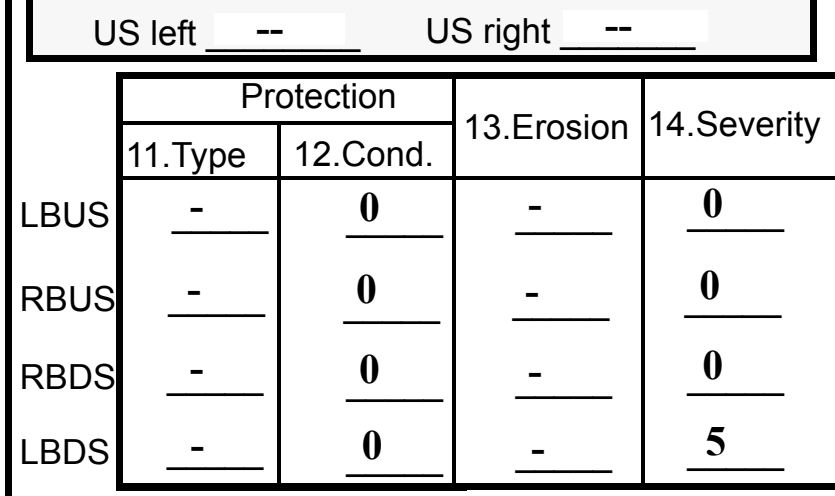

Bank protection types: 0- none; 1- < 12 inches;

2- < 36 inches; 3- < 48 inches;

4- $<60$ inches; 5- wall / artificial levee

Bank protection conditions: 1- good; 2- slumped;

3- eroded; 4- failed

Erosion: 0 - none; 1- channel erosion; 2-

road wash; 3- both; 4- other

Erosion Severity: 0 - none; 1- slight; 2- moderate;
Span length $\mathbf{4 0}$ (feet)
Bridge width $\underline{\mathbf{0}}$ (feet)

\section{Channel approach to bridge (BF):}

15. Angle of approach: $\mathbf{5}$

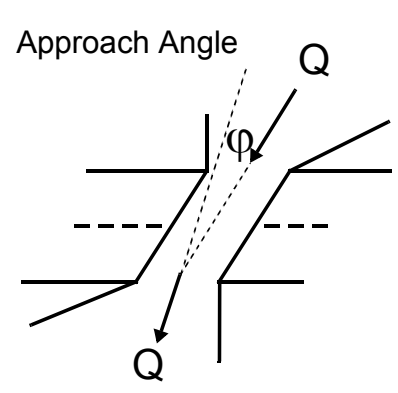

17. Channel impact zone 1 :

Where? 1 (LB, RB)

Range? US feet $\underline{\mathbf{3 0}}$

Channel impact zone 2:

Where? - $(L B, R B)$

Range? - feet (US, UB, DS) to feet $\underline{1 a}$

16. Bridge skew: $\mathbf{Y}$ Bridge Skew Angle

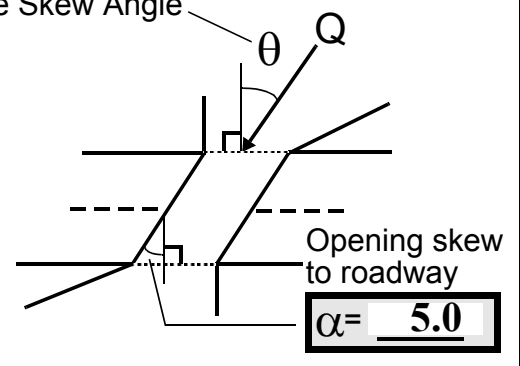

Exist? LB (Yor $N)$

Severity 0

(US, UB, DS) to $\underline{\mathbf{U B}}$ feet $\underline{\mathbf{N}}$

Exist? - $\quad(Y$ or $N)$

Severity -

Impact Severity: 0- none to very slight; 1- Slight; 2- Moderate; 3- Severe 
18. Bridge Type: The

1a- Vertical abutments with wingwalls

1 b- Vertical abutments without wingwalls

2- Vertical abutments and wingwalls, sloping embankment Wingwalls perpendicular to abut. face

3- Spill through abutments

4- Sloping embankment, vertical wingwalls and abutments

Wingwall angle less than $90^{\circ}$.

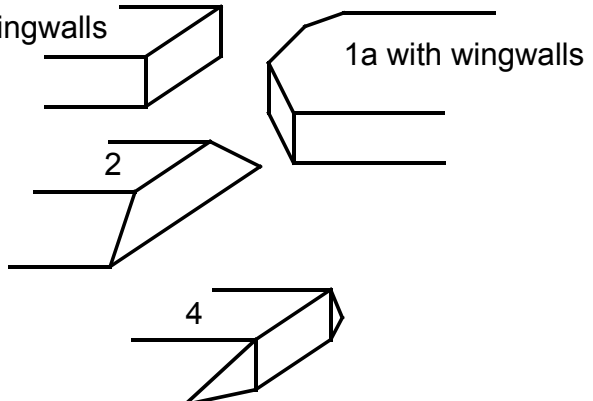

19. Bridge Deck Comments (surface cover variations, measured bridge and span lengths, bridge type variations, approach overflow width, etc.)

US and DS left banks have a strip of trees one bridge length wide along the banks then a dirt road and then a hay field on the US side and a lawn with a house DS.

Bridge dimension values shown are from the VTAOT files. Measured bridge length is $43.7 \mathrm{ft}$., bridge span is $\mathbf{4 0 . 1} \mathrm{ft}$., the roadway width is $29.9 \mathrm{ft}$., and the bridge width including the sidewalks and rails is $40 \mathrm{ft}$.

\section{Upstream Channel Assessment}

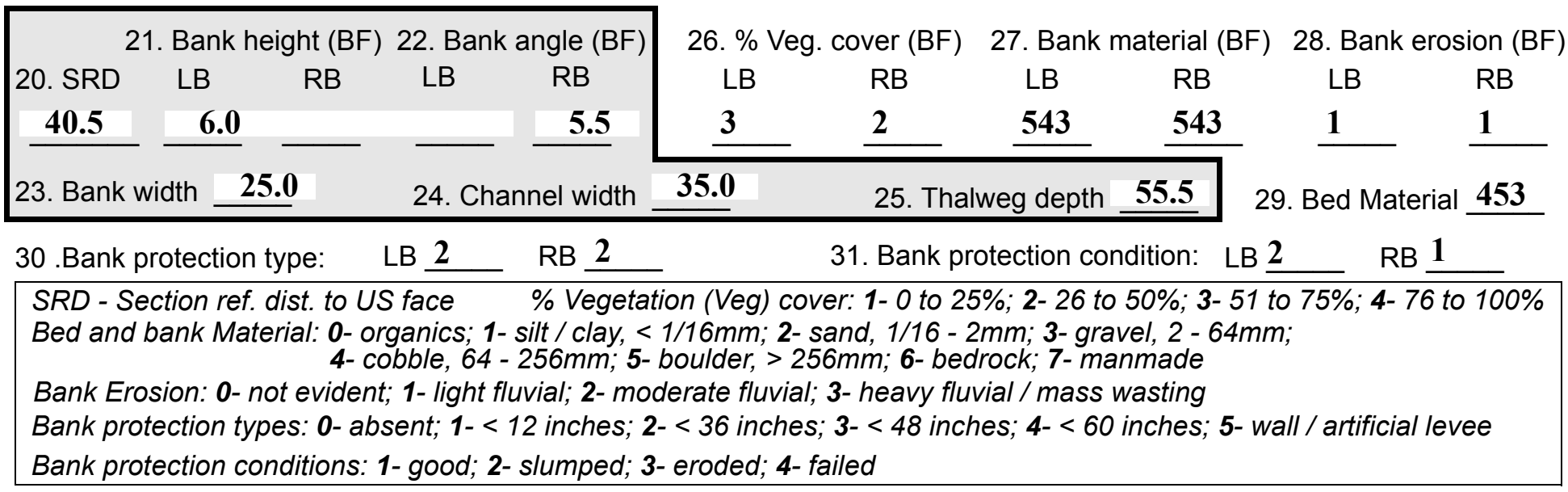

32. Comments (bank material variation, minor inflows, protection extent, etc.):

30. Bank protection on both banks is dumped type 3 stone near the bridge and type 2 stone beyond. On the right bank there was an old laid stone wall under the dumped stone. Large placed boulders are found at the end of the wingwalls to $35 \mathrm{ft}$. US on both the left and right bank. 
33.Point/Side bar present? $\mathbf{Y}(Y$ or $N$. if $N$ type ctrl-n pb)34. Mid-bar distance: $\mathbf{6 0}$

35. Mid-bar width: 25

36. Point bar extent: 10 feet $\underline{\text { US }}$ (US, UB) to 140 feet $\underline{\mathbf{D S}}$ (US, UB, DS) positioned $\underline{\mathbf{3 0}} \%$ LB to $100 \%$ RB

37. Material: $\mathbf{5 4 3}$

38. Point or side bar comments (Circle Point or Side; Note additional bars, material variation, status, etc.):

By count, the point bar composition is mostly cobbles, but the boulders dominate in size.

39. Is a cut-bank present? $\mathbf{Y}$ (Y or if $N$ type ctrl-n cb)

40. Where? $\underline{\text { LB }}$ (LB or RB)

41. Mid-bank distance: 130

42. Cut bank extent: 115 feet $\underline{\mathbf{U S}}$ (US, UB) to $\underline{\mathbf{2 0 0}}$ feet $\underline{\mathrm{US}}$ (US, UB, DS)

43. Bank damage: 1

(1- eroded and/or creep; 2- slip failure; 3- block failure)

44. Cut bank comments (eg. additional cut banks, protection condition, etc.):

There are roots exposed and some slumping, but the bank is still in good condition. Both banks show fluvial washing.

\section{Is channel scour present? $\underline{\mathbf{Y}}$ ( $Y$ or if $N$ type ctrl-n cs) $\quad$ 46. Mid-scour distance: $\underline{\mathbf{0}}$}

47. Scour dimensions: Length 15 Width $\underline{\mathbf{8}}$ Depth : $\underline{\mathbf{0 . 5}}$ Position $\underline{\mathbf{5}} \%$ LB to $\underline{\mathbf{1 5}} \%$ RB

48. Scour comments (eg. additional scour areas, local scouring process, etc.):

Scour is from $5 \mathrm{ft}$. US to $10 \mathrm{ft}$. under the bridge. Average thalweg depth is $0.75 \mathrm{ft}$. Some local scour is evident immediately downstream of boulders.

49. Are there major confluences? $\mathbf{N}$

( $Y$ or if $N$ type ctrl-n mc)

51. Confluence 1: Distance -

52. Enters on -

Enters on -

Confluence 2: Distance -

54. Confluence comments (eg. confluence name):

NO MAJOR CONFLUENCES ( $L B$ or $R B)$
50. How many? -

53. Type(1- perennial; 2- ephemeral)

Type (1-perennial; 2- ephemeral)

\section{Under Bridge Channel Assessment}

55. Channel restraint (BF)? LB 2

56. Height (BF)
LB RB
$\mathbf{3 4 . 0}-$
58. Bank width (BF) -
(1- natural bank; 2- abutment; 3- artificial levee)

Bed and bank Material: 0- organics; 1- silt / clay, < 1/16mm; 2- sand, 1/16 - 2mm; 3- gravel, 2 - 64mm; 4- cobble, 64 - 256mm; 5- boulder, > 256mm; 6- bedrock; 7- manmade

Bank Erosion: 0- not evident; 1- light fluvial; 2- moderate fluvial; 3- heavy fluvial / mass wasting

64. Comments (bank material variation, minor inflows, protection extent, etc.):

453 
65. Debris and Ice Is there debris accumulation?

$(Y$ or $N)$ 66. Where? $\mathbf{N}$

(1- Upstream; 2- At bridge; 3-Both)

67. Debris Potential ( 1- Low; 2- Moderate; 3- High)

68. Capture Efficiency 2

(1-Low; 2- Moderate; 3- High)

69. Is there evidence of ice build-up? 3 (Y or $N)$

Ice Blockage Potential $\mathbf{N}$

(1-Low; 2-Moderate; 3- High)

70. Debris and Ice Comments:

3

There is only $4 \mathrm{ft}$. of clearance between low chord and the stream bed, which suggests the capture efficiency is high. The historical form and area residents mentioned ice problems, however there is no evidence of ice damage at the bridge.

\begin{tabular}{|l|c|c|c|c|c|c|c|c|}
\hline Abutments & $\begin{array}{c}71 . \text { Attack } \\
\angle \text { (BF) }\end{array}$ & $\begin{array}{c}\text { 72. Slope } \angle \\
\text { (Qmax) }\end{array}$ & $\begin{array}{c}\text { 73. Toe } \\
\text { loc. (BF) }\end{array}$ & $\begin{array}{c}\text { 74. Scour } \\
\text { Condition }\end{array}$ & $\begin{array}{c}75 . \text { Scour } \\
\text { depth }\end{array}$ & $\begin{array}{c}\text { 76. Exposure } \\
\text { depth }\end{array}$ & 77. Material & 78. Length \\
\hline LABUT & & $\mathbf{5}$ & $\mathbf{9 0}$ & $\mathbf{2}$ & $\mathbf{0}$ & - & - & $\mathbf{9 0 . 0}$ \\
\hline RABUT & $\mathbf{1}$ & - & $\mathbf{9 0}$ & & & $\mathbf{2}$ & $\mathbf{0}$ & $\mathbf{3 9 . 5}$ \\
\hline
\end{tabular}

Pushed: $L B$ or RB

Toe Location (Loc.): 0- even, 1- set back, 2- protrudes

Scour cond.: 0- not evident; 1- evident (comment); 2- footing exposed; 3-undermined footing; 4- piling exposed; 5- settled; 6- failed

Materials: 1- Concrete; 2- Stone masonry or drywall; 3- steel or metal; 4- wood

79. Abutment comments (eg. undermined penetration, unusual scour processes, debris, etc.):

$-$

1

The left abutment toe is almost even with the left bank.

80. Wingwalls:

Exist? Material? Scour Scour Exposure $\begin{aligned} & 81 . \\ & \text { Angle? Length? }\end{aligned}$ Condition? depth? depth?

USLWW:

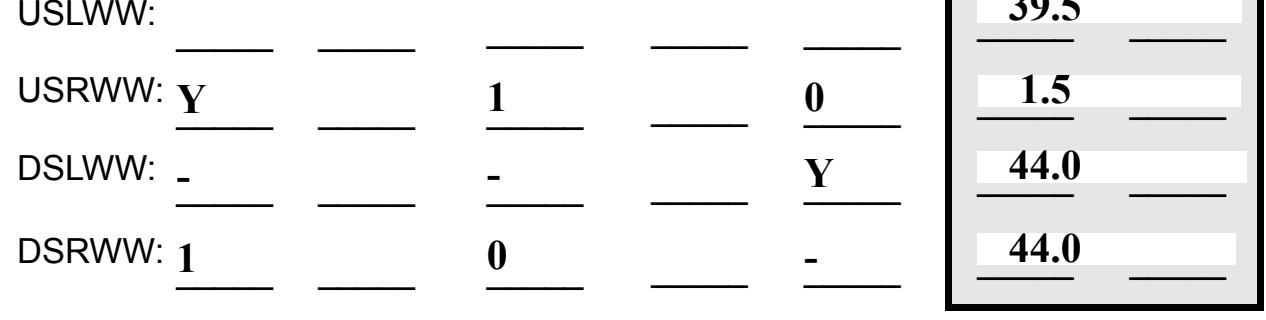

Wingwall materials: 1- Concrete; 2- Stone masonry or drywall; 3- steel or metal; 4- wood

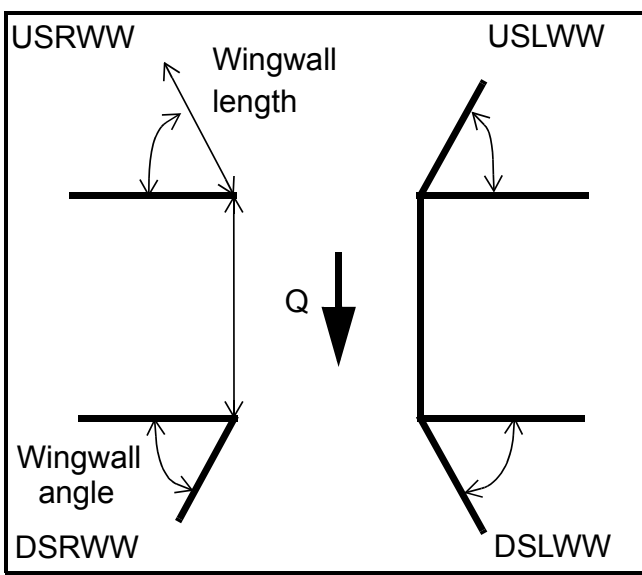

82. Bank / Bridge Protection:

\begin{tabular}{|l|l|l|l|l|l|l|l|l|}
\hline Location & USLWW & USRWW & LABUT & RABUT & LB & RB & DSLWW & DSRWW \\
\hline Type & - & $\mathbf{0}$ & $\mathbf{Y}$ & - & $\mathbf{1}$ & $\mathbf{1}$ & - & - \\
\hline Condition & $\mathbf{Y}$ & - & $\mathbf{1}$ & - & $\mathbf{2}$ & $\mathbf{2}$ & - & - \\
\hline Extent & $\mathbf{1}$ & - & $\mathbf{0}$ & $\mathbf{2}$ & $\mathbf{2}$ & $\mathbf{0}$ & $\mathbf{0}$ & - \\
\hline
\end{tabular}

Bank / Bridge protection types: 0- absent; 1- < 12 inches; 2- < 36 inches; 3- < 48 inches; 4- < 60 inches; 
83. Wingwall and protection comments (eg. undermined penetration, unusual scour processes, etc.):

-
-
-
-
-
3
1
3
3
1
3

\section{Piers:}

84. Are there piers? _ _ (Y or if N type ctrl-n pr)

\begin{tabular}{|l|l|c|c|l|l|l|l|}
\hline \multirow{2}{*}{$\begin{array}{l}85 . \\
\text { Pier no. }\end{array}$} & \multicolumn{3}{|c|}{ width (w) feet } & \multicolumn{3}{c|}{ elevation (e) feet } \\
\cline { 2 - 8 } & w1 & w2 & w3 & e@w1 & e@w2 & e@w3 \\
\hline Pier 1 & & $\mathbf{8 . 0}$ & $\mathbf{9 . 0}$ & $\mathbf{4 0 . 0}$ & $\mathbf{5 0 . 0}$ & $\mathbf{5 0 . 0}$ \\
\hline Pier 2 & & & & $\mathbf{1 0 . 0}$ & $\mathbf{4 0 . 0}$ & $\mathbf{1 0 . 0}$ \\
\hline Pier 3 & - & - & - & - & - & - \\
\hline Pier 4 & - & - & - & - & - & - \\
-
\end{tabular}

\begin{tabular}{|c|c|c|c|c|}
\hline Level 1 Pier Descr. & 1 & 2 & 3 & 4 \\
\hline 86. Location (BF) & & - & - & - \\
\hline 87. Type & & - & - & - \\
\hline 88. Material & & - & - & - \\
\hline 89. Shape & & - & - & - \\
\hline 90. Inclined? & & - & - & - \\
\hline 91. Attack $\angle(B F)$ & & - & - & - \\
\hline 92. Pushed & & - & - & - \\
\hline 93. Length (feet) & - & - & - & - \\
\hline 94. \# of piles & & - & - & - \\
\hline 95. Cross-members & & - & - & - \\
\hline 96. Scour Condition & & - & - & - \\
\hline 97. Scour depth & $\mathbf{N}$ & - & - & - \\
\hline 98. Exposure depth & - & - & - & - \\
\hline
\end{tabular}

LFP, LTB, LB, MCL, MCM, MCR, RB, RTB, RFP

1- Solid pier, 2- column, 3- bent

1-Wood; 2- concrete; 3- metal; 4- stone

1- Round; 2- Square; 3- Pointed

Y-yes; $N$ - no

$L B$ or $R B$

0- none; 1- laterals; 2- diagonals; 3- both

0- not evident; 1- evident (comment);

2- footing exposed; 3- piling exposed;

4- undermined footing; 5- settled; 6- failed 
99. Pier comments (eg. undermined penetration, protection and protection extent, unusual scour processes, etc.):

-

100.

\section{E. Downstream Channel Assessment}

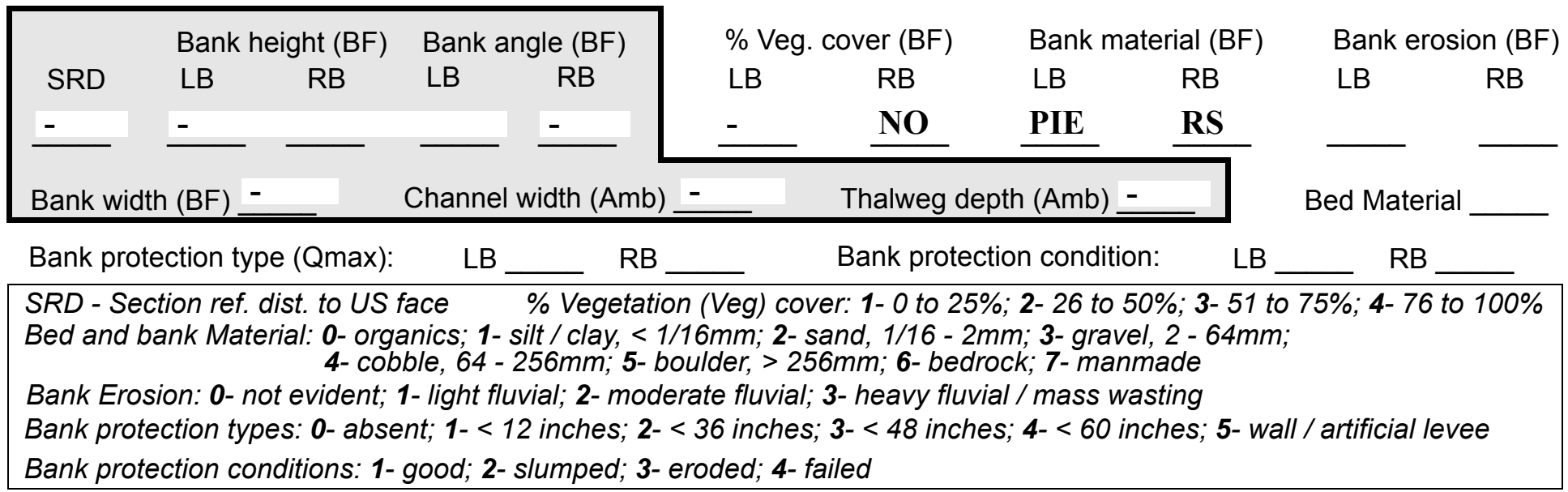

Comments (eg. bank material variation, minor inflows, protection extent, etc.):

2
1
7
7
1
1
453
5
5
1
1

There are artificial levees at the top of both banks downstream, which are built of large boulders and are considered bank protection. On the left bank the levee extends to 35 feet downstream of the bridge. About 35 feet

101. Is a drop structure present? do ( $Y$ or $N$, if $N$ type ctrl-n ds) 102. Distance: ___ feet

103. Drop: _ _ feet 104. Structure material: wn (1- steel sheet pile; 2- wood pile; 3- concrete; 4- other)

105. Drop structure comments (eg. downstream scour depth):

stream there is a transition from levee to stone fill on the left bank. On the right bank the levee extends to 20

feet downstream. There is a transition at 20 feet downstream on the right bank from the levee boulders to a stone wall, which continues to about 150 feet downstream. The stone wall is covered by soil and large trees. The percent vegetation on the left bank is small to 100 feet DS where it abuptly increases close to $100 \%$. On the right bank the percent vegetation cover is $50 \%$ up to 100 feet DS where it abruptly increases close to $100 \%$. The streambed consists of more cobbles downstream than upstream. 
106. Point/Side bar present? (Y or $N$. if $N$ type ctrl-n pb)Mid-bar distance:

Mid-bar width:

Point bar extent: feet

(US, UB, DS) to feet (US, UB, DS) positioned $\underline{\mathbf{N}}$ $\%$ LB to $\% \mathrm{RB}$ Material: $\mathbf{N O}$

Point or side bar comments (Circle Point or Side; note additional bars, material variation, status, etc.):

\section{DROP STRUCTURE}

Is a cut-bank present? (Y or if $N$ type ctrl- $n$ cb) Where? (LB or $R B)$

Mid-bank distance: $\underline{\mathbf{N}}$

Cut bank extent: = feet (US, UB, DS) to feet (US, UB, DS)

Bank damage: (1- eroded and/or creep; 2- slip failure; 3- block failure)

Cut bank comments (eg. additional cut banks, protection condition, etc.):

-

-

Is channel scour present? NO (Y or if N type ctrl-n cs) Mid-scour distance: POIN Scour dimensions: Length $\mathbf{T}$ Width BAR Depth: $\underline{\mathbf{S}}$

Positioned US \%LB to poi \%RB

Scour comments (eg. additional scour areas, local scouring process, etc.):

nt bar continues DS. See US channel assessment.

$\mathbf{N}$

Are there major confluences? - $(Y$ or if $N$ type ctrl-n $m c)$

Confluence 1: Distance Enters on (LB or $R B)$

How many? -

Confluence 2: Distance -

Enters on ( $L B$ or $R B)$

Type (1- perennial; 2- ephemeral)

Confluence comments (eg. confluence name):

Type NO (1- perennial; 2- ephemeral)

\section{CUT BANKS}

\section{F. Geomorphic Channel Assessment}

107. Stage of reach evolution

1- Constructed

2- Stable

3- Aggraded

4- Degraded

5- Laterally unstable

6- Vertically and laterally unstable 
108. Evolution comments (Channel evolution not considering bridge effects; See HEC-20, Figure 1 for geomorphic descriptors):

$\mathbf{N}$

$-$

$-$

-

$-$

$-$

NO CHANNEL SCOUR

Some local scour downstream of boulders.

N 


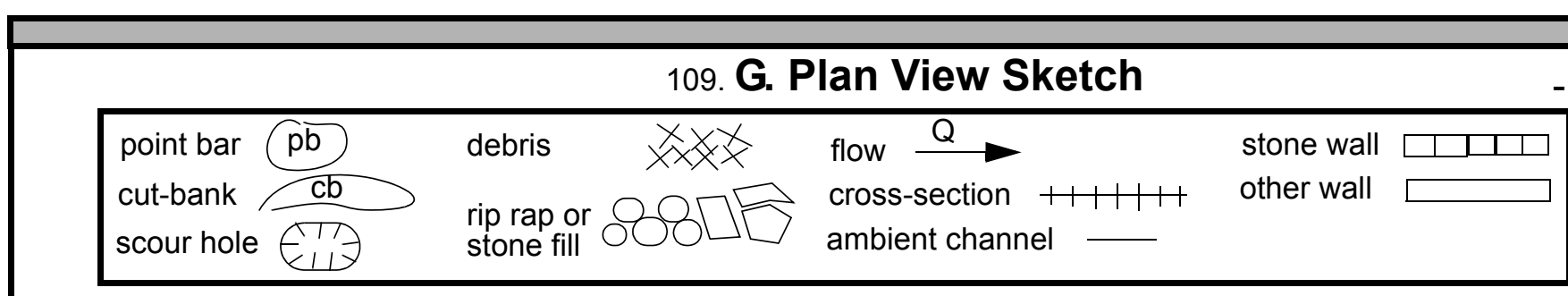


APPENDIX F:

SCOUR COMPUTATIONS 
SCOUR COMPUTATIONS

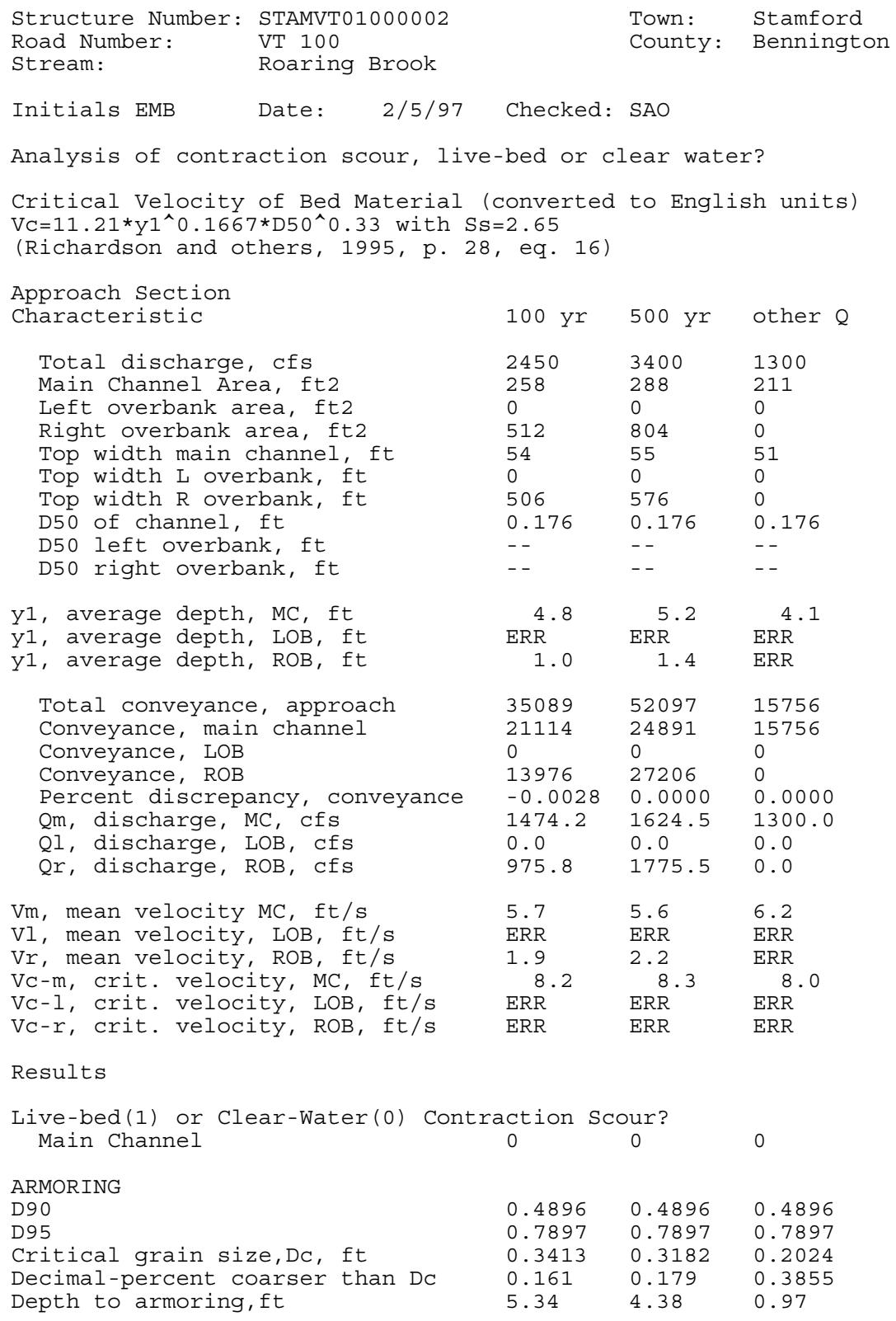


Clear water Contraction Scour in MAIN CHANNEL

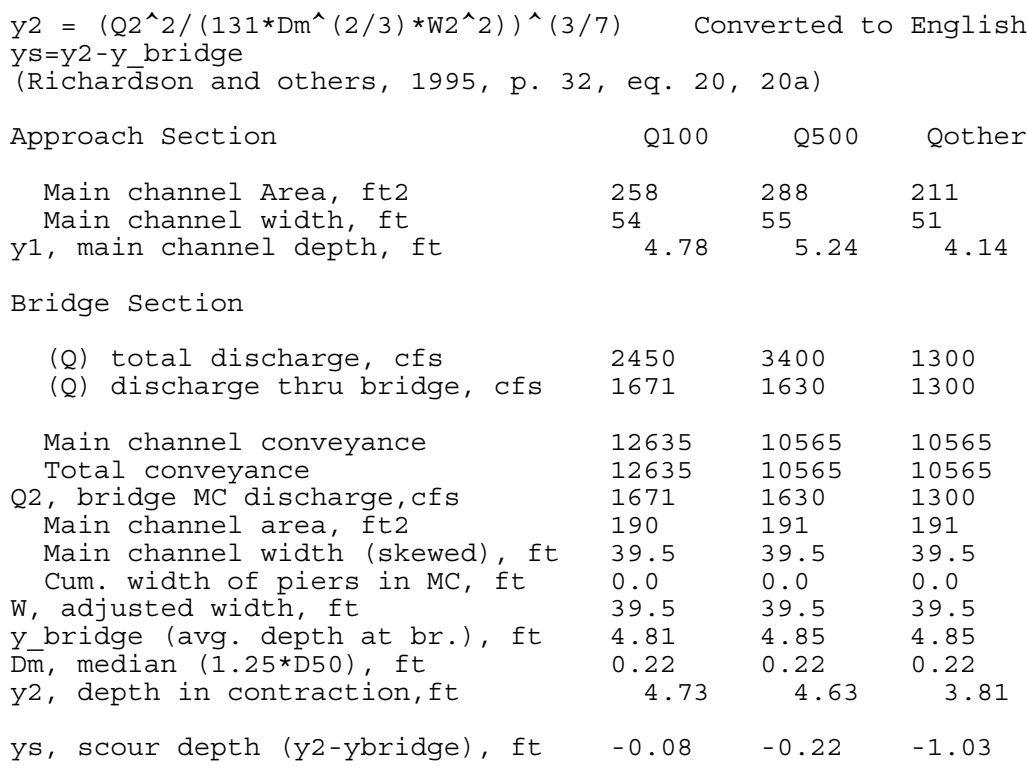

Pressure flow Scour (contraction scour for orifice flow conditions)

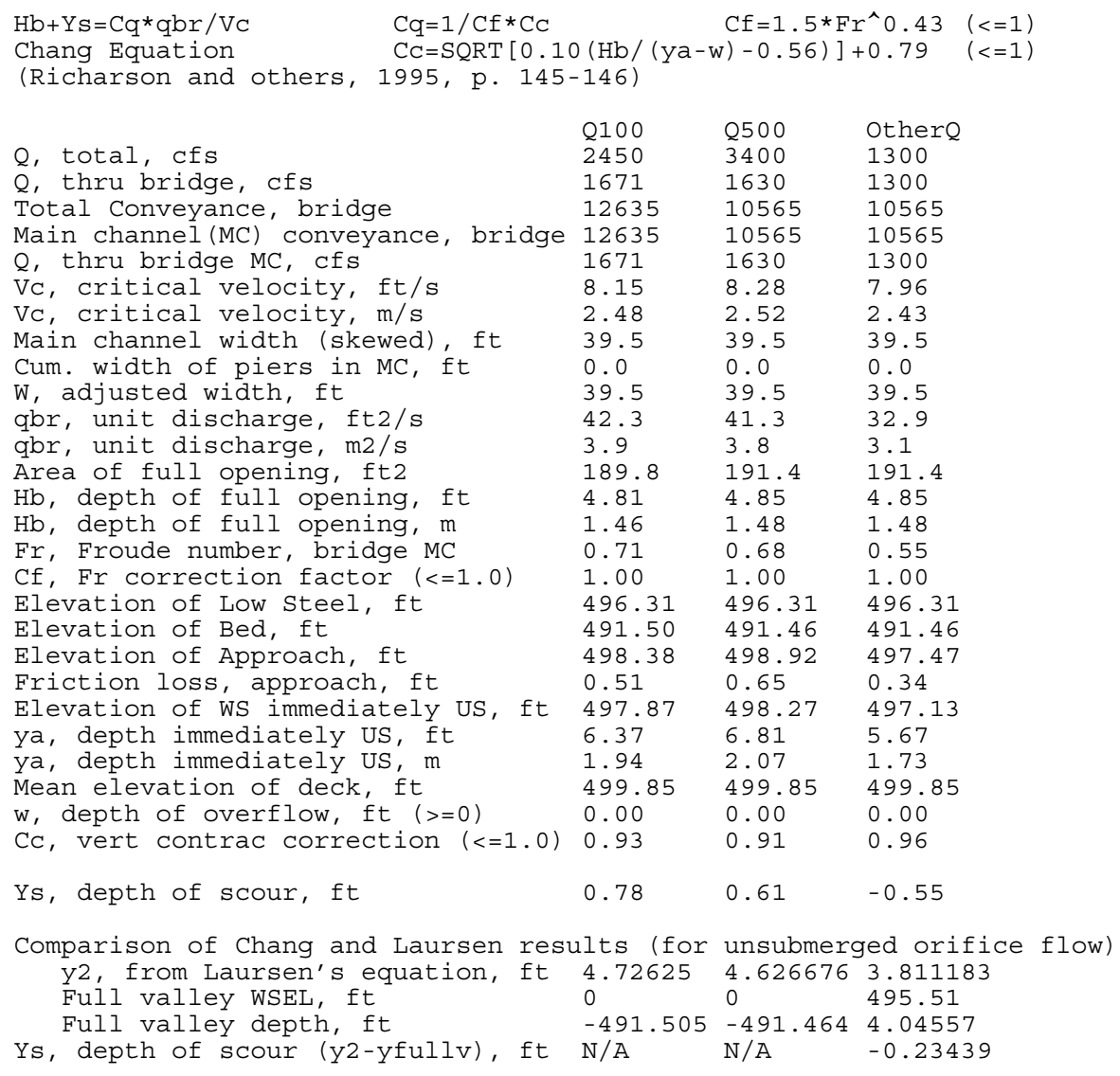


Abutment Scour

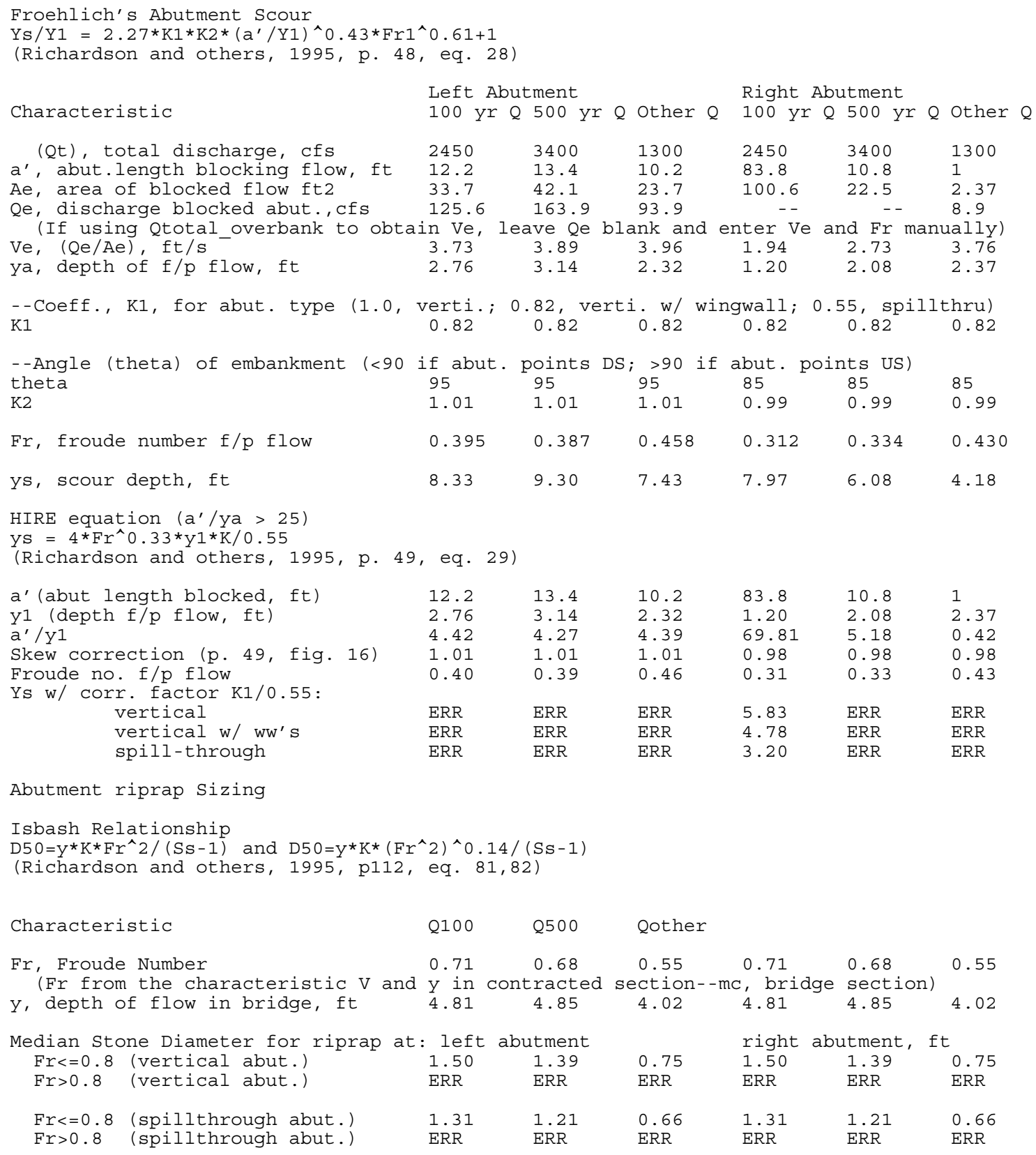

